\title{
Fiscal Policy in Unionized Labor Markets
}

\section{Citation}

Ardagna, Silvia. 2007. Fiscal policy in unionized labor markets. Journal of Economic Dynamics and Control 31(5): 1498-1534.

\section{Published Version}

http://dx.doi.org/10.1016/j.jedc.2006.05.009

\section{Permanent link}

http://nrs.harvard.edu/urn-3:HUL.InstRepos:2580048

\section{Terms of Use}

This article was downloaded from Harvard University's DASH repository, and is made available under the terms and conditions applicable to Other Posted Material, as set forth at http:// nrs.harvard.edu/urn-3:HUL.InstRepos:dash.current.terms-of-use\#LAA

\section{Share Your Story}

The Harvard community has made this article openly available.

Please share how this access benefits you. Submit a story.

Accessibility 


\title{
Fiscal Policy in Unionized Labor Markets
}

\author{
Silvia Ardagna ${ }^{1}$ \\ Harvard University
}

This version: May 2006

JEL: E62, E20, H61, J51.

\begin{abstract}
${ }^{1}$ I thank Alberto Alesina, Tiziana Brancaccio, Teresa Garcia-Mila, Peter Ireland, Tommaso Monacelli, Richard Rogerson, Fabio Schiantarelli, one anonymous referee, and seminar's participants at the University of Padova and at the CEPR conference "Political, Institutional and Economic Determinants of Fiscal Policy" for useful comments and suggestions. The usual disclaimer applies. Correspondence: Silvia Ardagna, Department of Economics, Littauer Center, Harvard University, Cambridge, MA 02138, USA. Email: sardagna@fas.harvard.edu. Phone: 1-617-495-8823. Fax: 1-617-495-7730.
\end{abstract}




\begin{abstract}
This paper investigates the effects of fiscal policy on economic activity, public finances, welfare, and income distribution in a dynamic general equilibrium model with a unionized labor market. The paper shows that debt-financed increases of public employment, wages of public sector employees, unemployment benefits and labor taxes put pressure on unions' wage claims, leading to higher private sector wages, lower employment, capital and output. In addition, increases of public employment, public wages and unemployment benefits increase workers' utility relative to the pre-policy change equilibrium during the transition, but not in the long-run. Instead, workers' utility decreases at any time horizon when labor taxes increase. Capitalists always benefit from increases in taxes on labor but their welfare decreases when public spending goes up. Finally, the paper investigates the extent to which the way the government balances its budget affects these results.
\end{abstract}




\section{Introduction}

Cross-country differences in the size and composition of the government budget have stimulated a lively debate on the effect of fiscal policy. Quite a large body of evidence has accumulated on the influence of fiscal policy instruments on the macroeconomy while less is known about the distributional effects of changes in the government budget's composition. ${ }^{1}$ Theoretically, macroeconomists have limited their analysis to the impact of a limited set of fiscal policy variables in economies with perfectly competitive labor markets. However, in several OECD countries (mainly continental Europe) unions are very powerful and their presence can influence the effects and the transmission mechanism of fiscal shocks. With the exception of Ardagna (2001), Cavallo (2003), Finn (1998), and Pappa (2004), macroeconomists have focused on the effect of government purchases of consumption and capital goods and of different types of tax rates. ${ }^{2}$ They have mostly overlooked the effects of changes in welfare spending and public employment even if these items account for almost three quarters of total government spending in OECD countries and since 1960 have become a larger share of total government spend-

\footnotetext{
${ }^{1}$ See, for example, Alesina et al. (2002), Alesina and Perotti (1997a), (1997b), Ardagna (2004), Giavazzi, Jappelli and Pagano (2000), and McDermot and Wescott (1996). See also Jantti (1997) and OECD (1991) for empirical evidence on the effect of transfers and taxation on income distribution.

${ }^{2}$ See Burnside et al. (2003), Baxter and King (1993), Devereux et al. (1996), Dotsey (1994), Ludvigson (1996), Mendoza and Tesar (1998), Ohanian (1997), Ramey and Shapiro (1998), and Rotemberg and Woodford (1992), among others, for general equilibrium models that study the effect of changes of government purchases of goods and of different types of taxes. Ardagna (2001), Cavallo (2003), Finn (1998), and Pappa (2004) introduce in a dynamic general equilibrium model with perfect competitive input markets the distinction between government consumption and government employment. For partial equilibrium models on the effect of public employment in unionized labor markets, see, instead, Algan, Cahuc, and Zylberberg (2002) and Forni and Giordano (2003). See also Horner, Ngai and Olivetti (2004) who focus on the relation between public ownership and unemployment.
} 
ing. ${ }^{3}$ Finally, theory has largely ignored distributional issues. In fact, the general equilibrium effects of changes in fiscal policy have mostly been addressed in models with a representative agent.

These considerations suggest possible extensions to the existing literature and motivate the present paper. Specifically, the goal of this paper is to extend the work of Ardagna (2001), Cavallo (2003), Finn (1998), and Pappa (2004) to an economy with unionized labor markets and heterogeneous agents and examine the macroeconomic and distributional consequences of changes in a wide set of fiscal instruments. To do so, the paper introduces fiscal policy into the monopoly union model of Maffezzoli (2001). In particular, the paper focuses on a two sector economy in which private firms produce a homogeneous consumption good using both capital and labor and the government hires public employees to provide public services. The labor market is unionized and heterogenous agents (capitalists, private and public sector employees, and unemployed workers) populate the economy.

The non competitive labor market framework allows to investigate the effect of changes to fiscal policy variables on unions' wage claims and, via the latter, on employment, capital accumulation and output. Alesina and Perotti (1997b), Daveri and Maffezzoli (1999) and Daveri and Tabellini (2000) provide empirical evidence in favor of the importance of this channel. Maffezzoli (2001) suggests that a monopoly union model better reproduces the Italian business cycle (but not the US one) relatively to the Hansen (1985) and Rogerson and Wright (1988) indivisible labor model. Zanetti (2004) shows that European business cycle statistics are better matched in a unionized labor market model than in a model with a competitive labor market. However, to the best of my knowledge, there is no contribution in the literature that systematically studies the effects of shocks to labor and capital taxes, government

\footnotetext{
${ }^{3}$ On average across OECD countries, government spending for welfare payments and public employment is equal to $72.1 \%$ of total government spending in 2002 and $65.76 \%$ in 1960.
} 
purchases of goods, public employment, wages of public employees, and unemployment benefits in a dynamic general equilibrium model with unionized labor markets. This is exactly what this paper does. Moreover, the presence of heterogeneous agents in the model allows to investigate the distributional and welfare effects due to changes in various types of public spending and taxes.

The paper reaches the following results. First, the benchmark model predicts that a debt-financed increase in government purchases of goods crowds out private consumption and has no effects on the supply-side of the economy as in a standard neoclassical model with inelastic individual labor supply. By contrast, increases in public employment, wages of public sector employees, unemployment benefits, and labor taxes affect output. In response to an increase in each of these variables, unions ask for higher wages. The increase in labor costs decreases employment in the private sector and the rate of return on capital, leading to a decrease in output. Increases in tax rates on capital income also affect negatively capital accumulation and output, but they have no effect on unions wage claims and employment in the private sector.

Second, fiscal policy shocks affect not only income of the various types of agents but also the distribution of workers between the private and public sector and between employment and unemployment. Hence, changes to fiscal policy have a different effect on welfare of the representative capitalist and of each type of worker (private employee, public employee and unemployed workers). Simulations suggest that debt-financed increases in public employment, public wages and unemployment benefits increase workers' utility relative to the pre-policy change equilibrium during the transition, but not in the long-run. Instead, workers' utility decreases at any time horizon when labor taxes increase. Capitalists always benefit from increases in taxes on labor income but their welfare decreases when public spending goes up. Income inequality decreases in the short-run when public employment, wages of 
public employees and unemployment benefits increase, but the effect switches sign after some years. The opposite occurs when tax rates on labor income increase. Finally, the paper shows the extent to which these conclusions are sensitive to the assumptions on how the government balances its intertemporal budget constraint.

The rest of the paper is organized as follows. Section 2 presents the benchmark model and the parameters used for the calibration. Section 3 details the response of output, employment, capital, consumption, welfare, income distribution, primary deficit, and public debt to changes in the fiscal policy items discussed above. Section 4 presents some sensitivity analysis and extensions to the benchmark model. The last section concludes.

\section{Benchmark model}

\subsection{The set-up}

The model adopts closely the monopoly union setup used in Maffezzoli (2001), and introduces a government sector and fiscal policy into the picture. The basic features of the economy can be summarized as follows. Infinitely lived individuals, perfectly competitive firms, monopolistic unions, and a government populate a closed economy. Households have perfect foresight and derive their lifetime utility from consumption of privately produced goods. There are $N_{k}$ capitalists and $N_{w}$ workers in the economy. Capitalists own the firms and their source of income is from capital and public bonds. They choose consumption and investment to maximize their utility over an infinite horizon. Workers, instead, consume all their disposable income in each period. They can be employed in the private or public sector or can be unemployed. If employed, workers offer inelastically one unit of labor and receive the wage rate prevailing in each sector. If unemployed, workers receive a subsidy from the government. 
Workers are organized in unions. Unions set the wage rate to maximize the present discounted value of their members' expected utility. In the benchmark model, unions operate only in the private sector. Labor unions are allowed to determine wages of both private and public sector workers in one of the extensions of the model. Firms are perfectly competitive and produce a homogeneous consumption good combining capital and labor with a constant return to scale technology. Technological progress is labor augmenting at the exogenous rate $x .{ }^{4}$ Finally, the government purchases final goods from the private sector, hires labor to produce public services, pays unemployment benefits, makes lump-sum transfers and, in the benchmark model, also sets the wage rate of public employees. The government finances its spending requirements by taxing labor and capital and by issuing debt. Public services may affect the productivity of capital and labor employed in the private sector.

\subsubsection{The household}

The representative capitalist maximizes the following intertemporal utility function

$$
\sum_{t=0}^{\infty} \beta^{t} \log \left(c_{k t}\right)
$$

subject to his budget constraint and the equation for the capital accumulation.

$$
\begin{gathered}
b_{t+1} x=\left(1+r_{t}^{b}\right) b_{t}+\left(1-\tau_{k t}\right) r_{t} k_{t}-c_{k t}-i_{t}+l s_{t} \\
k_{t+1} x=(1-\delta) k_{t}+i_{t}
\end{gathered}
$$

\footnotetext{
${ }^{4} X_{t+1}=X_{t} x$ where $X$ is the state of the technology and $x$ its gross rate of growth. The assumption of labor augmenting technological progress and the functional forms used to describe preferences and technology support balanced - growth path equilibria. Hence, without loss of generality, I present only the specification for the detrended model where all quantity variables (except employment) and wages are divided by the state of technology.
} 
$c_{k}$ represents the purchases of consumption goods by the representative capitalist and $i$ his investment in capital goods. $b$ are public bonds, $k$ capital goods, $r^{b}$ and $r$ are the real rate of return of public bonds and capital respectively. $x$ is the gross growth rate of technological progress, $\beta$ is the subjective discount factor, and $\delta$ is the rate at which capital depreciates. $l s$ are lump-sum transfers and $\tau_{k}$ is the tax rate on capital income. Income from public bonds is not taxed, depreciation allowances are zero, and there are no costs for installing new capital. Maximizing (1) subject to the constraints (2) and (3), simplifying and rearranging terms gives equations (4) and (5).

$$
\begin{gathered}
c_{k t}^{-1}=\beta x^{-1} c_{k t+1}^{-1}\left(1+\left(1-\tau_{k t+1}\right) r_{t+1}-\delta\right) \\
r_{t+1}^{b}=\left(1-\tau_{k t+1}\right) r_{t+1}-\delta
\end{gathered}
$$

Workers' utility depends on consumption of private goods: $U=\log \left(c_{w t}\right)$. I follow Gali, LopezSalido, and Valles (2003) and assume that, in each period, a worker spends all his disposable income on private consumption. Workers can be employed in the private or public sector, or they can be unemployed. If employed in the private or public sector, they offer inelastically one unit of labor, and receive the wage rate $w_{p}$ and $w_{g}$, respectively. If they are unemployed, they receive a subsidy $u$ from the government. Labor income is taxed at a rate $\tau_{N}$, unemployment benefits are not taxed..$^{5}$ In the benchmark model, workers don't receive lump-sum transfers; this assumption is relaxed in section 4.3. The following equations describe the consumption level of the three types of workers.

$$
\begin{gathered}
c_{p t}=w_{p t}\left(1-\tau_{N t}\right) \\
c_{g t}=w_{g t}\left(1-\tau_{N t}\right)
\end{gathered}
$$

\footnotetext{
${ }^{5}$ Although this assumption is too extreme for many countries, relaxing it does not change the qualitative nature of the results. In order to have an effect of labor taxes on the wage rate of the private sector, the crucial assumption is that governments tax unemployed benefits at a rate lower than that on labor income. This is the case in most countries.
} 


$$
c_{u t}=u_{t}
$$

Workers are randomly assigned to the private or public sector or to the unemployed pool. Workers in the private or public sector do not have different skills, nor jobs have different characteristics that affect preferences. The model assumes that workers receive a different salary in the two sectors. Workers are ex-ante identical. They become ex-post heterogenous, once the level of employment in the private and public sector is fixed, because they receive a different income according to their status. ${ }^{6}$ The labor force is organized in unions.

\subsubsection{The private sector}

The labor market structure in the private sector is taken from Maffezzoli (2001). In a nutshell, workers can sell their labor to only one firm at a time and each firm can hire from a pool of infinitely many workers. Workers are organized into a firm-specific trade union. Unions act as monopolists in the labor market and unilaterally set wages at the firm level. ${ }^{7}$ They maximize the expected present discounted value of their members' utility taking firms' labor demand and workers' reservation utility as given. ${ }^{8}$

\footnotetext{
${ }^{6}$ For simplicity, the paper assumes that there is no mobility of workers between private and public sector firms. Algan, Cahuc, and Zylberberg (2002) and Forni and Giordano (2003) rely on the same assumption to justify the difference of private and public sector's wages.

${ }^{7}$ It is well known that the monopoly union model does not lead to an efficient wage - employment outcome. The literature has often used this model for its simplicity. In particular, when one wants to study the effects of fiscal policy in non competitive labor markets, the monopoly union model simplifies the analysis and gives results that qualitatively do not differ from those that one can obtain in a model in which unions and firms bargain over the wage and the employment level. See, for example, Alesina and Perotti (1997b) for a discussion on monopolistic union models versus alternatives.

${ }^{8}$ In Maffezzoli (2001) unions are risk neutral and maximize the expected present discounted value of labor incomes. Also, unions act as a substitute for a competitive insurance market and sell actuarially fair insurance to their members. In this way, agents can insure against the risk of being unemployed, and, in equilibrium, the marginal utility of consumption
} 
Unions are large at the firm level, but they are small compared to the size of the economy and hence, it is not unreasonable to assume that unions also take the rental price of capital and fiscal policy variables as given.

Maffezzoli (2001) shows that unions can be aggregated into a representative union facing a representative firm. Also, under the assumption that pre-commitment is ruled out, the union and the firm cannot credibly commit to a sequence of future wage rates and of future demand for capital. Hence, the union and the firm effectively solve a sequence of non-cooperative dynamic games and employment in the private sector, the wage rate of private sector employees and the capital stock are determined period by period. The optimal solution of the union and firm problem is a Nash equilibrium for the game.

This set-up gives a somewhat simplified picture of the wage setting procedures in OECD countries. In particular, the model delivers the result that unions do not internalize the effect of the wage rate on aggregate variables. This is due to the fact that firms and unions cannot precommit, that unions operate at the firm level and are small at the economy level, and that they take the rental price of capital, members' reservation utility, and fiscal policy variables as given. Calmfors and Driffil (1988) suggest that such description may not be accurate for countries like the Scandinavian countries where unions are large at the economy-wide level, but it may represent quite well the situation of countries with intermediate degrees of unionization like Germany, France and Italy. Moreover, the assumptions in Maffezzoli (2001) make the model analytically tractable and avoid time-consistency problems that would arise if, for example, pre-commitment is not ruled out.

Firms produce a homogeneous consumption good with capital and labor, taking prices as given. In for employed and unemployed households are equalized. This allows to aggregate employed and unemployed households members into a representative household. In the present paper, unions do not need to perform this addtional task because agents are heterogeneous and heterogeneity is needed to study the effect of fiscal policy shocks on income distribution. 
order to take into account that services produced by public employees can influence the productivity of labor and capital, I follow Barro (1990) and modify a standard Cobb-Douglas production function as follows:

$$
Y_{t}=K_{t}^{a} N_{p t}^{1-a} S G^{\vartheta}
$$

where $Y$ represents aggregate output, $K$ the aggregate capital stock, ${ }^{9} N_{p}$ the number of workers employed in the private sector, $S G$ public services, $a$ the capital share, and $\vartheta$ measures the productivity of public services in the production of private goods.

In the set-up just described, the representative firm demands labor and capital according to the marginal productivity rule.

$$
\begin{gathered}
(1-a) \frac{Y_{t}}{N_{p t}}=w_{p t} \\
a \frac{Y_{t}}{K_{t}}=r_{t}
\end{gathered}
$$

The union chooses $w_{p}$ to maximize:

$$
\sum_{t=0}^{\infty} \beta^{t}\left[\frac{N_{p t}}{N_{w}} \log \left(w_{p t}\left(1-\tau_{N t}\right)\right)+\frac{N_{w}-N_{p t}}{N_{w}} U_{t}^{A}\right]
$$

subject to equations (9) and (10) and taking the rental price of capital, fiscal policy variables and members' reservation utility as given.

$U^{A}$ is the expected utility unions members receive when they are not employed in the private sector (i.e.: members' reservation utility), $N_{w}$ is the total number of workers (by assumption equal to unions'

\footnotetext{
${ }^{9}$ The aggregate capital stock is the sum of the capital stock that each capitalist of this economy accumulates. Hence, $K=N_{k} k$.
} 
membership), and $\frac{N_{p t}}{N_{w}}$ measures the probability of being employed in the private sector. ${ }^{10}$

Substituting (9) in (10) and the resulting equation in (12), we can derive the first order condition for the union:

$$
\log \left(w_{p t}\left(1-\tau_{N t}\right)\right)=U_{t}^{A}+a
$$

Thus, the equilibrium gross wage rate in the private sector, $w_{p}$, depends on workers' expected utility when they are not employed in the private sector, $U^{A}$, and on the tax rate on labor income, $\tau_{N}$.

$U^{A}$ is the weighted average of workers' utility if employed in the public sector and if unemployed (conditional on not being employed in the private sector), with weights equal to the probability of being employed in the public sector and of being unemployed:

$$
U_{t}^{A}=p_{t} \log \left(w_{g t}\left(1-\tau_{N t}\right)\right)+\left(1-p_{t}\right) \log \left(u_{t}\right)
$$

where, in equilibrium, $p_{t}=\frac{N_{g t}}{N_{w}-N_{p t}}$

Hence,

$$
\log \left(w_{p t}\left(1-\tau_{N t}\right)\right)=\frac{N_{g t}}{N_{w}-N_{p t}} \log \left(w_{g t}\left(1-\tau_{N t}\right)\right)+\frac{\left(N_{w}-N_{p t}-N_{g t}\right)}{N_{w}-N_{p t}} \log \left(u_{t}\right)+a
$$

Ceteris paribus, an increase in public employment, $N_{g}$, increases the probability of workers being employed in the public sector and decreases the one of being unemployed. If unemployment compensations, $u$, are lower than the after-tax wage in the public sector, $w_{g}\left(1-\tau_{N}\right)$, unions' members reservation utility increases, leading to higher wages in the private sector. Similarly, an increase in $w_{g}$ (or in $u$ ) has a ceteris paribus positive effect on $w_{p}$, because it raises workers' expected utility of not being employed in the private sector. A ceteris paribus increase in the tax rate on labor income, $\tau_{N}$,

\footnotetext{
${ }^{10}$ As discussed above, Maffezzoli (2001) allows the union to offer its members actuarially fair insurance against the risk of becoming unemployed. This assumption also tackles the possibility that ex-post unemployed workers leave the union.
} 
has, instead, two opposite effects on $w_{p}$. On the one hand, the increase in $\tau_{N}$ reduces the net wage of the worker, leading to an increase in the pre-tax real wage faced by the employer. On the other, it reduces the after-tax wage of a public sector worker, decreasing workers' reservation utility and moderating unions' wage demand. Differentiating (13) with respect to $\tau_{N}$, however, one can show that the first effect dominates. Hence, wages for private sector workers increase in response to a ceteris paribus increase in $\tau_{N}$ too.

\subsubsection{The government}

The government hires public employees $N_{g}$ and produces services $S G$ according to the production function $S G_{t}=N_{g t}^{\eta}$. For simplicity, in the benchmark model, public services do not affect the productivity of labor and capital used by private sector firms (i.e.: $\vartheta=0$ in (9)). Thus, public employment related expenses are a pure waste as in Finn (1998). In section 4.1, I relax this assumption and public employees produce services that have a positive effect on private production (i.e.: $\vartheta \neq 0$ in (9)).

Wages for the public sector employees, $w_{g}$, are exogenous in the benchmark model. The paper assumes that the government unilaterally fixes them. In most countries, wages in the public sector are the outcome of negotiations between governments' officials and public employees' unions. The assumption that $w_{g}$ is exogenous is a shortcut to simplify the theoretical framework. As shown in section 4.2, the qualitative nature of the results of the benchmark model holds when we allow unions to set wages in the public sector. ${ }^{11}$

\footnotetext{
${ }^{11}$ The literature has followed different approaches in modeling the wage setting practices in the private and public sector. Calmfors and Horn (1986) introduce public employment in a monopolistic union model, but they assume that the union chooses the same wage rate for workers in the public and private sector and that labor is the only factor of production. Holmund (1997) allows for different wages, but he models the wage bargaining between unions, firms and the government in
} 
The government also purchases goods from the private sector, pays lump-sum transfers and unemployment subsidies. It finances its expenditures by taxing labor and capital at the rates $\tau_{N}$ and $\tau_{k}$ respectively and by issuing debt. Equation (16) describes the government budget constraint:

$B_{t+1} x=B_{t}\left(1+r_{t}^{b}\right)+\overline{N_{g t}} \overline{w_{g t}} w_{p t}+\left(N_{w}-N_{p t}-\overline{N_{g t}}\right) \bar{u}_{t} w_{p t}+\overline{g_{t}} Y_{t}-\tau_{N t}\left(w_{p t} N_{p t}+\overline{w_{g t}} w_{p t} \overline{N_{g t}}\right)-\tau_{k t} r_{t} K_{t}+L S_{t}$

where $B$ is the aggregate stock of public debt the government issues $\left(B=b N_{k}\right)$ and $L S$ is the total amount of lump-sum transfers. In the benchmark model, the government pays lump-sum transfers only to capitalists, hence $L S=l s N_{k} .^{12}$ It is useful to assume that the government fixes the purchases of goods as a share of output, $\left(G_{t}=\overline{g_{t}} Y_{t}\right)$, public employment as a share of total population, ${ }^{13}$ $\left(N_{g t}=\overline{N_{g t}}\right)$, and the wage rate of the public sector employees and unemployment benefits as a share of the wage in the private sector, $\left(w_{g t}=\overline{w_{g t}} w_{p t}\right.$ and $u_{t}=\bar{u}_{t} w_{p t}$, respectively). The government also faces a no-Ponzi game condition, $\lim _{T \rightarrow \infty}\left(\Pi_{t=0}^{T}\left(1+r_{t}^{b}\right)\right) B_{T}=0$, which implies that the present value of government expenditures equals the present value of tax revenues plus the initial stock of public debt. The government sets lump-sum transfers $L S$ to balance its budget constraint intertemporally. ${ }^{14}$

a model without capital accumulation. On the one hand, extending the model following Holmund (1997) would complicate the analysis beyond the scope of this work. On the other, following Calmfors and Horn (1986) one cannot study the effect that changes in government wages have on the economy, shutting down a channel that is empirically important as shown, for example, by Alesina et al. (2002). Finally, note also that the empirical work by Alesina et al. (2002) suggests that the direction of causality goes from public sector wages and employment to wages and employment in the private sector. This gives some support to the assumption that government wages and employment are exogenous. However, the strength and robustness of this evidence is ultimately an important empirical question that this paper does not address.

${ }^{12}$ Section 4.3 investigates the implication of this assumption.

${ }^{13}$ Total population is equal to $N_{k}+N_{w}=1$.

${ }^{14}$ Note that public debt is "Ricardian" in the sense that, given its initial value and the values of the exogenous fiscal policy instruments, public debt's time path does not affect equilibrium allocations. Hence, in the benchmark model, setting 
Finally, in each period, the law of motion for the aggregate capital stock

$$
K_{t+1} x=K_{t}(1-\delta)+I_{t}
$$

and the economy's resource constraint hold.

$$
Y_{t}=N_{k} c_{k t}+N_{p t} c_{p t}+N_{g t} c_{g t}+\left(N_{w}-N_{p t}-N_{g t}\right) c_{u t}+I_{t}+\overline{g_{t}} Y_{t}
$$

where $I$ represents aggregate investment and $K$ is the aggregate stock of capital.

\subsection{Solving the model}

The sequence of endogenous quantity and price variables $\left\{b_{t+1}, k_{t+1}, c_{k t}, c_{p t}, c_{g t}, c_{u t}, N_{p t}, Y_{t}, i_{t}, r_{t}\right.$, $\left.w_{p t}, r_{t}^{b}\right\}$ that solves the first order conditions for households, unions and firm's problems (equations (4) - (8), (10), (15), and (11)), equations (9), (16) - (18), the sequence of the exogenous variables $\left\{\tau_{N t}, \tau_{k t}\right.$, $\left.\overline{N_{g t}}, \bar{w}_{g t}, \bar{u}_{t}, \overline{g_{t}}, l s_{t}\right\}$, and the initial values of the predetermined ones $\left\{b_{t}, k_{t}\right\}$ define the equilibrium of the model economy. Numerical solutions of changes to the exogenous fiscal policy variables involve the computation of the long-run, balanced-growth path equilibria before and after the change occurs and of the transitional dynamics between the two steady-state equilibria. Equations (4) - (10) and (15) (18) define a system of stationary non-linear difference equations that describe the dynamic behavior of the economy. To determine the solution for the endogenous variables, I loglinearize the system around the steady-state values of the variables and apply the method of Blanchard and Kahn (1980). ${ }^{15}$

\footnotetext{
lump-sum transfers so that the no-Ponzi game condition holds affects only public debt's time path.

${ }^{15}$ The equations defining the balanced-growth path equilibrium, the simplified set of equilibrium conditions, and the loglinearized system of difference equations used to determine the solution for the endogenous variables are available upon request.
} 


\subsection{Welfare analysis}

To compute the welfare cost of a particular policy, the paper follows Ohanian (1997) and calculates the additional level of consumption to give to each agent of the economy so that his utility obtained with the policy change equals that in the pre-policy change case. More specifically, the paper finds the value of $\xi_{i}$ that satisfies the following equation:

$$
\sum_{t=0}^{J} \beta^{t}\left\{\log \left(c_{i t}^{*}\left(1+\xi_{i}\right)\right)-\bar{U}_{i 0}\right\}=0
$$

where: $\bar{U}_{i 0}$ is defined as the utility level in the pre-change scenario $\bar{U}_{i 0}=\log \left(c_{i 0}\right), c_{i t}^{*}$ is consumption of agent $i$ at the time and after the policy change, $i$ refers to the representative capitalist, employee of the private sector, employee of the public sector and unemployed worker, and $J=200$.

The paper also computes welfare costs for a "hypothetical" worker (i.e.: a worker who does not know if she will be employed in the private or public sector or if she will be unemployed) and a "hypothetical" household (i.e.: an agent who can be a capitalist with probability $N_{k}$ or a worker with probability $\left.N_{w}\right){ }^{16}$

\subsection{Calibration}

Table 1 shows the parameter values used to calibrate the model at a yearly frequency. The calibration of the values for the technology and preferences' parameters follows the literature and sets $\alpha=1 / 3, \delta=$ 0.1 , and $\beta=0.98$. In the benchmark model, $\vartheta=0$ and the remaining parameters are the unweighted

\footnotetext{
${ }^{16}$ This implies finding the value of $\xi$ that solves the following equations: (i) $\sum_{t=0}^{J} \beta^{t}\left\{\bar{U}_{w t}^{*}-\bar{U}_{w 0}\right\}=0$ and (ii) $\sum_{t=0}^{J} \beta^{t}\left\{\left[N_{k} \log \left(c_{k t}^{*}(1+\xi)\right)+\bar{U}_{w t}^{*}\right]-\left[N_{k} \log \left(c_{k 0}(1+\xi)\right)+\bar{U}_{w 0}\right\}=0\right.$, where: $\bar{U}_{w t}^{*}=$ $N_{w}\left[\frac{N_{p t}^{*}}{N_{w}} \log \left(c_{p t}^{*}(1+\xi)\right)+\frac{\bar{N}_{g t}^{*}}{N_{w}} \log \left(c_{g t}^{*}(1+\xi)\right)+\frac{\left(N_{w}-N_{p t}^{*}-\bar{N}_{g t}^{*}\right)}{N_{w}} \log \left(c_{u t}^{*}(1+\xi)\right)\right]$ and $\bar{U}_{w 0}=$ $N_{w}\left[\frac{N_{p 0}}{N_{w}} \log \left(c_{p 0}\right)+\frac{\bar{N}_{g 0}}{N_{w}} \log \left(c_{g 0}\right)+\frac{\left(N_{w}-N_{p 0}-\bar{N}_{g 0}\right)}{N_{w}} \log \left(c_{u 0}\right)\right]$.
} 
average data of ten European countries (Belgium, Finland, France, Germany, Italy, the Netherlands, Norway, Spain, Sweden, United Kingdom) in the period 1965 - 1995. Section 4.4 calibrates the model using US data in the same period. Tax rates on labor and capital income are from Daveri and Tabellini (2000) and Daveri and Maffezzoli (1999) who provide an update of the series by Mendoza et al. (1994). The other data are from the OECD Economic Outlook no. 62.

The benchmark model sets the tax rate on labor income, $\tau_{N}$, at $36.67 \%$ and the one on capital income, $\tau_{k}$, at $32.09 \%$. The value of public employment as a share of the labor force, $\bar{N}_{g}$, and the wage premium between wages in the private and public sector, $\overline{w_{g}}$, are equal to $16.76 \%$ and $112.42 \%$, respectively. The replacement rate, $\bar{u}$, is the ratio of per-capita transfers to the compensation workers in the private sector receive and it is equal to $25.17 \%$. Government spending for final goods as a share of GDP, $\bar{g}$, is equal to $5.70 \%$. In the initial steady-state, I set lump-sum transfers so that the initial value of the debt-to-GDP ratio is equal to $50.36 \%$, the average value of the ten European countries between 1965 and 1995. I keep lump-sum transfers constant at this value for 100 periods. Then, I adjust them to ensure that the no-Ponzi game condition holds. ${ }^{17}$ The average real per-capita growth rate of output is equal to $2.41 \%$. Total population is normalized to 1 and $N_{w}$ and $N_{k}$ are equal to $83.27 \%$ and $16.73 \%$ respectively, where $16.73 \%$ is the average value of the ratio of self-employed workers to the labor force

\footnotetext{
${ }^{17}$ Lump - sum transfers from $t=1, \ldots . . J$ are set to satisfy the following equation: $\left\{B_{0}\left(1+r_{0}^{b}\right)+N_{g 0} w_{g 0}+\left(N_{w}-N_{p 0}-N_{g 0}\right) u_{0}+G_{0}-\tau_{N 0}\left(N_{p 0} w_{p 0}+N_{g 0} w_{g 0}\right)-\tau_{k 0} r_{0} K_{0}+L S_{0}\right\}$$$
+\sum_{t=1}^{J-1}\left\{N_{g t} w_{t}+\left(N_{w}-N_{p t}-N_{g t}\right) u_{t}+G_{t}-\tau_{N t}\left(N_{p t} w_{p t}+N_{g t} w_{g t}\right)-\tau_{k t} r_{t} K_{t}\right\}\left\{x^{t}\left(\prod_{s=1}^{t}\left(1+r_{s}\right)^{-1}\right\}\right.
$$$$
+\sum_{t=1}^{T_{1}} L S_{0}\left\{x^{t}\left(\prod_{s=1}^{t}\left(1+r_{s}\right)^{-1}\right\}+\sum_{t=T_{1}+1}^{J-1} L S_{t}\left\{x^{t}\left(\prod_{s=1}^{t}\left(1+r_{S}\right)^{-1}\right\}=0\right.\right.
$$

where variables at $t=0$ assume the value in the pre - policy change balanced - growth equilibrium, $T_{1}=100$, and $J=200$. 
in the ten European countries between 1965 and $1995 .{ }^{18}$ Section 4.4 checks the robustness of the results to the parameters used to calibrate the model.

Table 2 shows the actual values of the employment and the unemployment rate and of the ratios of capital, investment, and consumption to GDP, together with the model's steady-state values of the same variables. When I use the average data over the entire period to calibrate the model, the steady-state value of the capital-to-output ratio is equal to $156.1 \%$, the ones of investment and total consumption as a share of GDP are $19.4 \%$ and $74.9 \%$, respectively. The sum of the employment rate in the private and public sector is $70.4 \%$ and the unemployment rate is $12.9 \%$. In the data, the average capital-to-output ratio across European countries over the period 1965 - 1995 is $202.6 \%$, private investment as a share of GDP is $18.7 \%$, public investment as a share of GDP is $3 \%$, private consumption, net export, and government consumption are $58.19 \%, 0.14 \%$, and $19 \%$, respectively. ${ }^{19}$ The ratio of employment in the private and public sector to the labor force is $77.33 \%$ and the unemployment rate is $5.92 \%$. Thus, the model implies a lower capital-to-output ratio and employment rate and a higher unemployment rate, but it fits well the data of private investment and private consumption. In fact, in the model, the ratio of consumption-to-GDP is the residual component of the national income identity since public investment and net export are zero by assumption.

\footnotetext{
${ }^{18}$ I measure the number of capitalists in the economy using the fraction of the population in the ten European countries that does not receive any dependent labor income. The qualitative nature of the results does not change if I calibrate the model setting, for example, $N_{k}$ equal to $33 \%$, where $33 \%$ is the average value of the profits-to-GDP ratio in the ten European countries between 1965 - 1995 .

${ }^{19} 19 \%$ includes the ratio of non-wage government spending as a share of GDP ( $g$ in the model) that is equal to $5.7 \%$ in the data.
} 


\section{Policy experiments}

The paper analyzes the effects of a permanent, unanticipated, debt-financed $1 \%$ increase of each of the exogenous fiscal policy variables, keeping the others fixed at their initial level. The paper simulates the model for 200 periods and gives data as percentage deviations from the pre-policy change balanced-growth equilibrium for all variables except the ratios of public debt, primary deficit, primary expenditure and revenues to GDP. I express the latter as percentage points deviations. Impact effects correspond to changes at the time of the increase in the fiscal policy item. Long-run effects measure deviations between the pre and post-policy change balanced-growth equilibria.

\subsection{Effects on the macroeconomy}

This section looks at the effects of fiscal policy changes on employment, capital accumulation and output. It discusses the principal channels through which fiscal policy instruments influence the macroeconomy in the monopoly union model, highlights the similarities and differences in the transmission mechanism relatively to a model with perfect competitive labor markets and summarizes the results of the numerical simulations.

Columns 1 and 2 of Table 3 (and the first four charts of Figure 1) show the impact and long-run effects of a $1 \%$ increase of government consumption, $\bar{g}$. An increase in $\bar{g}$ reduces resources available to the private sector. This generates a negative wealth effect that crowds out capitalists' consumption. As in a standard neoclassical model with inelastic labor supply, the increase in $\bar{g}$ does not have any effect on the supply-side of the economy, neither on impact nor in the long-run, because, by assumption, government consumption of goods does not influence workers' utility. In addition, unions are small

and operate at the firm level taking the rate of return on capital as given. Hence, employment in the 
private sector does not depend on $\bar{g}$, and output and the capital stock remain unchanged.

In a model with elastic individual labor supply, employment in the private sector, output and investment change following a shock to $\bar{g}$. However, the direction of the changes depends on the elasticity of the individual labor supply, on how government spending is financed (lump-sum versus distortionary taxation), on the time path of taxes and on the persistence of the spending shock. ${ }^{20}$ The negative effect of the increase of government consumption on aggregate consumption, instead, holds in a model with elastic labor supply when this model is calibrated using plausible parameters' values. In fact, as Gali, Lopez-Salido and Valles (2003) and Forni, Monteforte, and Sessa (2006) show the existence of both sticky prices and of Ricardian and non-Ricardian households are necessary conditions to obtain a positive correlation between public and private consumption.

Fiscal policy has non zero effects on the economy through the labor market and the supply-side when it involves changes in public employment, public wages and unemployment benefits. Let's consider first public employment (see columns 3 and 4 of Table 3 and the first four charts of Figure 1). An increase in public employment affects the fall-back position of the private sector union. Union members' reservation utility increases as the probability of finding a job in the public sector goes up.

\footnotetext{
${ }^{20}$ For example, Ardagna (2001) shows that in response to a debt-financed increase in $\bar{g}$ (as the experiment considered in this section), the negative wealth effect generated by the fiscal shock leads to a derease in households' consumption and to an increase in the supply of hours of work, assuming that both consumption and leisure are normal goods. Employment in the private sector, output and investment increase on impact. Given that the level of the capital stock is fixed at the time of the policy change, the capital-labor ratio decreases, leading to a lower wage rate and higher rate of return on capital. Over time, the capital stock increases, driving the capital-labor ratio up. In the new long - run balanced growth equilibrium, the capital-labor ratio, hence $w$ and $r$, is back to its initial value. Output, employment, and the capital stock are higher than in the pre-policy change equilibrium. See Burnside, Eichenbaum, and Fisher, J. (2003) for a model in which public spending is, instead, financed by distortionary taxation and Alesina et al. (2002) for a review of the literature.
} 
As a result, private sector unions push up their wage claims and private sector employment falls by $0.55 \%$ on impact. Due to the fact that firms and unions cannot precommit, that unions operate at the firm level and are small at the economy level, and that they take the rental price of capital and fiscal policy variables as given, employment in the private sector depends only on fiscal policy and technology parameters. Hence, $N_{p}$ converges to the new steady-state value immediately as public employment increases. ${ }^{21}$ The level of the capital stock is fixed at the time of the policy change. As employment falls, the capital-labor ratio increases and the rate of return on capital decreases. Output in the first period of the transition is lower than its value in the initial steady by $0.37 \%$ and investment decreases too. As investment decreases, the capital stock falls, further reducing output. But, as capital decreases, its rate of return goes up. In the new steady-state, $w_{p}$ and $r$ are back to their initial values. Output, employment in the private sector, and the capital stock are lower than in the pre-policy change equilibrium. Also, the increase in public employment does not compensate for the decrease in private employment and unemployment increases as well.

These results are in line with the empirical evidence. For example, Malley and Moutos (1998) analyze the effect of public employment on private and aggregate employment in Sweden during the period 1964-1990. They show that the sharp increase in public employment crowded out employment in the private sector and contributed to the increase in unemployment. Algan, Cahuc and Zylberberg (2002) reach similar results using a panel of OECD countries from 1960 to 2000.

Finally, note that in a model with perfect competitive labor markets as in Ardagna (2001), Cavallo (2003), Finn (1998), and Pappa (2004), an increase in public employment has similar qualitative effects

\footnotetext{
${ }^{21}$ The equation for employment in the private sector can be obtained substituting equations $N_{g t}=\overline{N_{g t}}, w_{g t}=\overline{w_{g t}} w_{p t}$ and $u_{t}=\bar{u}_{t} w_{p t}$ in equation (15). Solving for $N_{p t}$, we obtain $N_{p t}=N_{w}-\frac{\overline{N_{g t}}\left[\log \left(\overline{w_{g t}}\right)+\log \left(1-\tau_{N t}\right)-\log \left(\overline{u_{t}}\right)\right]}{\log \left(1-\tau_{N t}\right)-\log \left(\overline{u_{t}}\right)-a}$.
} 
on macroeconomic variables. However, the propagation mechanism of the shock is different from the one just described. In a competitive labor market model, the increase in public employment and the negative wealth effect associated with it lead to a decline of consumption and leisure assuming that both goods are normal. Labor supply increases, but the increase in the supply of hours of work only partially matches the increase in $\overline{N_{g}}$. There is a shift of labor out of the private and into the public sector. This generates the decrease in employment in the private sector which triggers the fall in investment, output and the capital stock.

Let's now turn to the effects of a $1 \%$ increase in public employees' wages and unemployment benefits (see columns 5-8 of Table 3 and the first four charts of Figure 1). Changes in these policy variables have the same qualitative effect of changes of public employment and the shocks are transmitted via the same channel. In fact, when $\overline{w_{g}}$ and $\bar{u}$ increase, the expected income workers receive if they are not employed in the private sector goes up. Hence, union members' reservation utility increases and so does the union's fall-back position. This leads to the same results illustrated for the case of a surge in public employment. ${ }^{22}$

Columns 9 and 10 of Table 3 (and the first four charts of Figure 1) show the impact and long-run effects of a $1 \%$ increase in labor income taxes, $\tau_{N}$. Once again, the fiscal shock affects employment, output, investment and the capital stock through the same channel identified in the case of an increase in public employment, wages of public sector workers and unemployment benefits. Quantitatively, however, note that the effects from a $1 \%$ increase in $\tau_{N}$ are smaller than the ones from a $1 \%$ increase in

\footnotetext{
${ }^{22}$ In perfect competitive labor market models, it is not possible to analyze the effect of changes in unemployment benefits. In a model with perfect competitive labor markets one can introduce transfers to leisure and interpret them as unemployment benefits compensations. Note that changes in such transfers would have the same qualitative effects (but with the opposite sign) of changes of labor income taxes.
} 
$\bar{N}_{g}, \overline{w_{g}}$, and $\bar{u}$. Also, it is important to note that, contrary to a standard neoclassical model with perfect competitive labor markets, the response of macroeconomic variables to changes in labor taxes does not depend on the elasticity of substitution of the individual labor supply. In a standard neoclassical model, the income and substitution effects work in opposite directions: the first leads to a decrease in leisure, the second generates an increase in $L$ when labor taxes increase. Hence, the response of the supply of hours of work and the equilibrium of the economy depend on the relative strength of the two effects and a $1 \%$ increase in $\tau_{N}$ generates consequences similar to those of the monopoly union model if the substitution effect dominates. However, Dotsey (1994) and Ludvigson (1996) show that, for this to happen, the individual labor supply has to assume very high, and probably, unrealistic values. ${ }^{23}$

Finally, an increase in the capital income tax rate reduces the net of tax return on saving, leading to an increase in capitalists' consumption at the time of the policy change. However, on impact, $\tau_{k}$ does not affect employment in the private sector. Given that the level of the capital stock is fixed at the time of the policy change, output, the capital-labor ratio, hence, $r$ and $w_{p}$, do not change. Workers' consumption does not vary as well, because their disposable income remains at the initial value. Driven by the increase in capitalists' consumption, total private consumption increases by $0.17 \%$ on impact and aggregate investment decreases by $0.67 \%$. Over time, the decrease in saving and investment reduces the capital stock and output and it decreases the capital-labor ratio. In the new balanced-growth path equilibrium, $r$ is higher and $w_{p}$ is lower than in the pre-policy change case. As in the case of $\bar{g}$, in this model, both the qualitative results and the propagation mechanism are similar to those of a standard neoclassical model.

\footnotetext{
${ }^{23}$ See Rotemberg and Woodford (1992) and Ramey and Shapiro (1998) for general equilibrium models that generate predictions consistent with the empirical evidence in the US. These models assume competitive labor markets but departure from the standard neoclassical approach in other dimensions.
} 


\subsection{Effects on public finances}

The second part of Table 3 (and the fifth and sixth charts of Figure 1) show that the largest deterioration in public finances occurs when wages of the public sector employees or the number of public sector workers increase, while an identical percentage rise (1\%) in unemployment benefits or public consumption has a smaller effect. Increases in labor and capital tax rates reduce primary deficit and public debt and changes in labor tax rates have larger effects than changes in capital tax rates. It is interesting to note that the change in primary deficit and public debt following a $1 \%$ change in the capital tax rate is lower, in absolute value, than the change in any spending item except government consumption. Hence, the model suggests that the most effective measures to improve the stance of public finance are decreases in public employment, wages of public sector employees, and unemployment benefits and/or increases in labor tax rates. Changes to government consumption and tax rates on capital income seem to play only a minor role. Note that these predictions of the model are somewhat consistent with empirical literature on fiscal consolidations, which suggests that fiscal consolidations focusing on cuts to the government wage bill and welfare payments are more likely to permanently reduce the stock of public debt (see, for example, Alesina and Ardagna (1998)) and Ardagna (2004)).

\subsection{Effects on welfare and income distribution}

What is the effect of various changes in fiscal policy on income distribution? Let's begin with the welfare effects due to a $1 \%$ increase in public employment (see columns 3 and 4 of Table 3 ). As discussed in section 3.1, the wage rate of private sector employees, $w_{p}$, increases. Because income of public sector and unemployed workers is linked to $w_{p}$, income, consumption, and utility of all types of workers increase in the short-run. However, in the new steady-state equilibrium, workers' utility 
converges to its value before the increase in $\bar{N}_{g}$ because the wage rate goes back to its pre-policy change level. Note that, even though life-time utility of a public and a private sector employee and of an unemployed worker increases, welfare of a "hypothetical" worker, (i.e.: a worker who does not know if she will be employed in the private or public sector or if she will be unemployed), decreases. In fact, although the probability of being employed in the public sector increases with $\bar{N}_{g}$, the probability of being employed in the private sector decreases and the one of being unemployed increases because the increase in $\bar{N}_{g}$ generates a decrease in $N_{p}$ and an increase in unemployment. This outweighs the positive effect of the higher wage rate on workers' welfare and the expected lifetime utility of a "hypothetical" worker goes down. Income inequality, measured by the change in the Gini coefficient, decreases in the short-run. However, it is higher in the post-policy change equilibrium than in the pre-policy change one..$^{24}$

Effects on welfare and income distribution due to a $1 \%$ increase in public employees' wages and in unemployment benefits are similar to the ones following a $1 \%$ increase in public employment. The only exception is the increase in income inequality occurring at the time of the increase in $\bar{w}_{g}$. Welfare costs due to a $1 \%$ increase in labor taxes differ among agents. Among workers, the unemployed are the only ones who gain from the increase in labor taxes. Their disposable income goes up on impact, because unemployment subsidies are tied to the wage rate in the private sector and because they are

\footnotetext{
${ }^{24}$ Table 1 shows that public employment has sharply increased since the mid-sixties. One of the arguments in the literature to explain this trend suggests that governments use public employment to redistribute resources across groups or geographical regions and that the size of redistribution through this channel is large. For example, Alesina et al. (1999) argue that about one half of the wage bill of Southern Italy can be seen as a pure transfer from the North. In the model, public employment redistributes resources from capitalists to workers. However, as discussed, the model suggests that this policy benefits workers and decreases income inequality only temporarily.
} 
tax-exempt. Welfare of private sector and public sector workers, instead, decreases both on impact and in the steady-state, since the increase in the wage rate is smaller than the one in taxation and, thus, consumption decreases. Workers' aggregate consumption goes down as well. By contrast, more resources are available to capitalists whose consumption and utility increase. The Gini coefficient goes up on impact, but, in the long-run, it decreases by $1.5 \%$. Finally, a $1 \%$ increase in capital taxes generates an increase in capitalists' consumption and utility because, as explained in section 3.1, capitalists' saving decreases due to the fall in the net of tax return on saving. Workers' consumption and utility, instead, decrease along the transition path and the new steady state due to the permanent reduction in $w_{p}$. Income inequality decreases in response to an increase in the tax rate on capital income.

In summary, increases in government employment, unemployment benefits and wages of public sector employees hurt capitalists but increase life-time welfare of each type of worker. The opposite occurs when tax rates increase. However, if we consider that fiscal policy also changes the probability of being employed and that workers are ex-ante identical (hence, in each period they can be either employed or unemployed), their expected life-time utility decreases even when $\bar{N}_{g}, \bar{w}_{g}$, and $\bar{u}$ increase. Thus, these measures generate a welfare cost for a "hypothetical" worker too.

\section{Sensitivity and extensions}

This section discusses some sensitivity analysis and extensions to the benchmark model. First, I allow public employment to influence the productivity of private production. Second, I introduce unions in the public sector and endogeneize the choice of public employment and government wages. Third, I relax the assumption that only capitalists receive lump-sum transfers. Finally, I calibrate the model setting fiscal policy variables at their smallest values across the European countries in the sample, at 
their average values in the sub-periods 1965 - 1970 and 1991 - 1995, or I use average US data over the period 1965 - 1995. I also compare the effects of fiscal policy in Europe and the US. Fiscal policy experiments are the same as in section 3 , unless otherwise noted.

\subsection{Productivity of public services}

In order to take into account that services produced by public employees can influence the productivity of labor and capital used by firms in the private sector, I relax the assumption that $\vartheta$ in (9) is equal to 0 . From the private sector and public sector production functions, one obtains $Y_{t}=K_{t}^{a} N_{p t}^{1-a} N_{g t}^{\lambda}$ where $\lambda=\eta \vartheta$ measures the productivity of public workers in the production of privately produced goods. I calibrate the model setting the parameter $\lambda$ equal to $1 / 3,2 / 3$, and 1 . Figure 2 shows the impulse response functions to a $1 \%$ increase in public employment for different values of $\lambda$. For comparison, Figure 2 also plots the impulse response functions for the benchmark model $(\vartheta=0)$.

Changing the parameter $\lambda$ has effect on the percentage deviation from the initial steady state of employment in the private sector, capital, output, total private consumption, public debt, primary deficit, utility of the different agents, and the Gini coefficient. ${ }^{25}$ As expected, the negative effect on the macroeconomy is smaller if public employment contributes to the productivity of private employment and capital. Ceteris paribus, we obtain the same qualitative results than in the benchmark model (i.e.: a negative effect on economic activity following an increase in $\overline{N_{g}}$ ) if $\lambda$ is smaller or equal to 0.58 . For $\lambda$ greater than 0.58 , instead, a $1 \%$ increase in $\overline{N_{g}}$ leads to an increase in private sector employment, capital, output, and total private consumption. Results about the effects of changes of fiscal policy variables except public employment do not depend on the assumption about the productivity of public

\footnotetext{
${ }^{25}$ Charts detailing the response of utility of different agents and the Gini coefficient are not shown, but they are available upon request.
} 
workers. To my knowledge, there are no papers that calibrate the productivity of public workers. Finn (1998) considers a model in which public capital affects the production of private goods, and fixes the parameter that measures the productivity of public capital in the production function to about one half of the parameter that measures the productivity of private capital. Using the same criteria and setting $\lambda$ equal to $1 / 3$, results of the benchmark model still hold.

\subsection{Endogenous choice of public employment and government wages}

To endogeneize the choice of public employment and government wages I model the public sector along the lines of the private sector and allow monopoly unions to unilaterally set wages of public sector workers at the firm level. As unions in the private sector, public sector unions are large at the firm level, but they are small compared to the size of the economy and they cannot credibly commit to a sequence of future wage rates. Hence, in each period, public sector unions maximize utility of their members taking public sector firms' labor demand, workers' reservation utility, the rental price of capital and fiscal policy variables as given. Moreover, I assume that hiring decisions in the private and public sector happen simultaneously and that each sector takes employment and the wage rate of the other sector as given. Hence, private and public sector unions set wages non-cooperatively. Algan, Cahucm and Zylberberg (2002) follow this approach, while Forni and Giordano (2003) also consider the case in which private and public sector unions set wages cooperatively.

Public sector firms produce public services and they set the level of public employment $N_{g}$. Different approaches have been followed in the literature to model public firms' objective function. In the benchmark model, Algan, Cahucm and Zylberberg (2002) consider the case of a benevolent government that maximizes the difference between the public good's social value and its cost, and, hence, 
the government hires public workers up to the point where the marginal utility of the public good produced by public employees is equal to its social costs. Overemployment in the public sector may, instead, occur if politicians pursue personal objectives and, for example, see public enterprises also as a vehicle for policy-makers to gain voters' support and enlarge their constituencies. I take this latter view and, contrary to private sector firms, I assume that public sector firms are not only interested in maximizing profits, but also care about the level of the wage bill of public employees. They see higher public sector wages or public employment as a way to enhance popularity among voters. Hence, public sector firms choose the level of employment to maximize the following objective function: $\widetilde{\Pi}=S G_{t}-w_{g t} N_{g t}+\Omega\left(w_{g t} N_{g t}\right) . S G_{t}$ is the output of the public enterprise that is produced only with labor according to the production function $S G_{t}=N_{g t}^{\eta} . S G_{t}-w_{g t} N_{g t}$ measures the operating profits of public sector firms. $\Omega>0$ measures the extent by which governments care about their workers' wage bill. Hence, a higher value of $\Omega$ signals that public sector firms value $N_{g}$ and/or $w_{g}$ more than profit maximizers' firms. ${ }^{26}$

In this set-up, public sector firms' optimal demand of labor is:

$$
w_{g t}=\frac{\eta}{1-\Omega} \frac{S G_{t}}{N_{g t}}
$$

The public sector union chooses $w_{g}$ to maximize $\sum_{t=0}^{\infty} \beta^{t}\left[\frac{N_{g t}}{N_{w}} \log \left(w_{g t}\left(1-\tau_{N t}\right)\right)+\frac{N_{w}-N_{g t}}{N_{w}} \widetilde{U_{t}^{A}}\right]$ subject to public sector firm's labor demand and taking the rental price of capital, fiscal policy variables and members' reservation utility as given. Note that $\frac{N_{g t}}{N_{w}}$ measures the probability of being employed in the public sector and $\widetilde{U^{A}}$ is the expected utility unions members receive when they are not employed

\footnotetext{
${ }^{26}$ Forni and Giordano (2003) also assume that the public employer's objective function combines a profit motivation with a political motivation. However, they model the latter assuming that the government cares about total employment. The assumption that the government is concerned about the wage bill of public employees simplifies the algebra.
} 
in the public sector $\left(\widetilde{U_{t}^{A}}=\widetilde{p}_{t} \log \left(w_{p t}\left(1-\tau_{N t}\right)\right)+\left(1-\widetilde{p}_{t}\right) \log \left(u_{t}\right)\right.$ where $\left.\widetilde{p}_{t}=\frac{N_{p t}}{N_{w}-N_{g t}}\right)$. The first order condition for the public sector union problem is similar to (12) and in equilibrium the wage of government sector workers is:

$$
\log \left(w_{g t}\left(1-\tau_{N t}\right)\right)=\frac{N_{p t}}{N_{w}-N_{g t}} \log \left(w_{p t}\left(1-\tau_{N t}\right)\right)+\frac{\left(N_{w}-N_{p t}-N_{g t}\right)}{N_{w}-N_{p t}} \log \left(u_{t}\right)+(1-\eta)
$$

Relatively to the benchmark case in section 3, the equilibrium of the economy also includes equations (20) and (21) among the first order conditions, $N_{g t}$ and $w_{g t}$ among the endogenous variables, and $\Omega$ and $\eta$ among the parameters to calibrate. To simulate the effect of a permanent, unanticipated, debt-financed $1 \%$ increase of each of the exogenous fiscal policy variables $\left\{\tau_{N t}, \tau_{k t}, \bar{u}_{t}, \overline{g_{t}}\right\}$ and of the parameter $\Omega$, I follow the same steps described in section 2.2.

Table 4 summarizes the results for the case in which $\eta=1 / 3$ and $\Omega=0.10$ in the initial steadystate. The table shows that qualitative nature of the results delivered by the benchmark model holds. Note that a $1 \%$ increase in the value of the parameter that measures the extent by which governments care about their workers' wage bill has effects similar to those generated by changes in $N_{g t}$ and $w_{g t}$ in the benchmark economy even though endogenous variables' response to the shock is mitigated. In response to a $1 \%$ increase in $\Omega$, public employment increases by $0.18 \%$ and, at the same time, wages in the government sector decrease by $0.008 \%$. This reduces the extent by which wages in the private sector increase and employment in the private sector decreases. However, the magnitude of the changes in response to an increase in $\Omega$ are increasing in the value of the parameter and the response of the economy is quite large if, for example, $\Omega=0.25$. While this set of results is clearly only a first step to understand much more complex relations among wage negotiations in the private and public sector, their interactions and the effects on the macroeconomy, evidence offered in Table 4 and Figure 3 is encouraging. In fact, results of the benchmark economy hold when the public sector labor market 
is modeled along the same lines of the private sector.

\subsection{The effect of governments' decisions on how to balance the budget constraint}

The benchmark model analyzes the effect of debt-financed changes in fiscal policy variables and assumes that the government balances its budget intertemporally by changing the amount of lump-sum transfers paid to capitalists. What if lump-sum transfers are distributed also to workers? Because workers consume all their income in each period, changes in lump-sum transfers affect workers' consumption and, hence, contrary to the benchmark model, public debt's time-path affects equilibrium allocations. To investigate the implications of this modification for the results discussed so far, this section considers the case in which lump-sum transfers are paid in equal amount to all the households of the economy. However, I simplify the analysis and assume that, in response to changes in $\bar{g}, \overline{N_{g t}}$, $\overline{w_{g t}}, \bar{u}_{t}, \tau_{N t}, \tau_{k t}$, lump-sum transfers are now used to balance the government budget constraint in each period, rather than intertemporally, and, hence, I set $B=0$. While this assumption is likely to affect the timing and the magnitude of the response of macroeconomic variables to changes in fiscal policy, nevertheless it is useful to show the directions in which results of the model in section 3 change if lump-sum transfers are also paid to workers.

In the modified model, consumption of the three types of workers depends also on lump-sum transfers $\left(c_{p t}=w_{p t}\left(1-\tau_{N t}\right)+l s_{t}, c_{g t}=w_{g t}\left(1-\tau_{N t}\right)+l s_{t}, c_{u t}=u_{t}+l s_{t}\right)$ and, hence, unions objective function changes as well. As a result, equation (15) becomes equal to: $\log \left(w_{p t}\left(1-\tau_{N t}\right)+l s_{t}\right)=$

$\frac{N_{g t}}{N_{w}-N_{p t}} \log \left(w_{g t}\left(1-\tau_{N t}\right)+l s_{t}\right)+\frac{\left(N_{w}-N_{p t}-N_{g t}\right)}{N_{w}-N_{p t}} \log \left(u_{t}+l s_{t}\right)+\frac{a w_{p t}\left(1-\tau_{N t}\right)}{w_{p t}\left(1-\tau_{N t}\right)+l s_{t}}$, and the government budget constraint is equal to: $L S_{t}=l s_{t}\left(N_{k}+N_{w}\right)=\overline{N_{g t}} \overline{w_{g t}} w_{p t}+\left(N_{w}-N_{p t}-\overline{N_{g t}}\right) \bar{u}_{t} w_{p t}+\overline{g_{t}} Y_{t}-\tau_{N t}\left(w_{p t} N_{p t}+\right.$ $\left.\overline{w_{g t}} w_{p t} \overline{N_{g t}}\right)-\tau_{k t} r_{t} K_{t}$. 
Table 5 shows the extent by which results in Table 1 change following the change in the model's structure. Interestingly and contrary to the benchmark model in section 3, changes to government consumption of goods and services and changes in tax rates on capital income affect the macroeconomy also through the labor market. In fact, changes in these budget items require changes in lump-sum transfers which, in turn, affect private wages unions demand and private sector employment. Consider, for example, columns (1) and (2). A $1 \%$ increase in $\bar{g}$ leads to a decrease in lump-sum transfers of $0.48 \%$ on impact and in the long-run. The decrease in $l s_{t}$ affects income of the private sector worker and their fall-back options. As a result, private sector unions push up their wage claims and private sector employment falls by $0.03 \%$ on impact. The level of the capital stock is fixed at the time of the policy change. As employment falls, the capital-labor ratio increases and the rate of return on capital goes down. Output in the first period of the transition is lower than its value in the initial steady by $0.03 \%$ and investment decreases too. As investment goes down, the capital stock falls, further reducing output. But, as capital decreases, its rate of return goes up. In the new steady-state, $w_{p}$ and $r$ are back to their initial values. Output, employment in the private sector, and the capital stock are lower than in the pre-policy change equilibrium and such policy change implies a welfare cost for all agents of this economy. In summary, changes in $l s_{t}$ induce similar qualitative responses that changes in $\overline{N_{g t}}, \overline{w_{g t}}, \bar{u}_{t}$, $\tau_{N t}$ have in the benchmark model.

Columns (3)-(8) show the effect of a $1 \%$ increase in $\overline{N_{g t}}, \overline{w_{g t}}, \bar{u}_{t}$. Given that changes in these fiscal policy variables lead to a decrease in lump-sum transfers and that lump-sum transfers operate in the economy through the same channels as changes in $\overline{N_{g t}}, \overline{w_{g t}}, \bar{u}_{t}$, the effect on the macroeconomy is amplified. In fact, private sector unions demand higher wages both because $\overline{N_{g t}}, \overline{w_{g t}}, \bar{u}_{t}$ increase and 
because $l s_{t}$ decreases.$^{27}$ Instead, when taxes on labor income increase, lump-sum transfers increase as well and the two policy changes have opposite effects on unions' objective function: the increase in $\tau_{N t}$ tends to push unions' wage claims up, the increase in $l s_{t}$ tends to push unions' wage claims down. Columns (9) and (10) show that the latter effect dominates. Hence, results are completely reversed from those in the benchmark model.

Summarizing, results discussed in section 3 depend on the assumption that lump-sum transfers are paid only to capitalists. Our previous conclusions concerning the effect of changes in public employment, wage of public employees and unemployment benefits strengthened if the government pays lump-sum transfers to workers too. Instead, in response to an increase in tax rates on labor income, results are the opposite of those in the benchmark model. In the framework of this model, this is due to the assumption that workers consume all their income in each period, and hence, changes in lump-sum transfers affect workers' consumption and equilibrium allocations.

\subsection{Fiscal reforms in different time periods and countries}

The qualitative nature of the results does not change when I use the smallest values of the fiscal policy variables across the European countries in the sample in calibrating the benchmark model. The magnitude of the changes obviously differs and it is increasing in the level of the fiscal policy variables: a $1 \%$ increase in policy instruments has a lower impact on the macroeconomy, public finances, welfare and income inequality when I calibrate the model using the smallest values of the fiscal policy variables

\footnotetext{
${ }^{27}$ Note that the magnitude of the results in Table 5 is not directly compared with that of results in Table 1 . In fact, not only the final steady state values of the endogenous variables are different but also the initial steady state values differ due to the absence of $l s_{t}$ in equations (6), (7), (8), and (15) of the benchmark model, and the difference in the government budget constraint in the two models.
} 
than when I use the average values over all sub - periods.

I also checked whether the effects of each policy shock differ across time periods, calibrating the model with data in the years 1965 - 1970 and 1991 - 1995. As Table 1 shows, the values of all fiscal policy variables, except the ratio of wages in the public and private sector, increase over time, while the real per capita growth rate and the ratio of self-employed workers to the labor force decline. Results are similar to those in the benchmark model and they are stronger when I use the most recent data. Hence, ceteris paribus, the effect of a fiscal reform implemented between 1991 and 1995 is larger than that which the same reform would have had should it had taken place between 1965 and 1970 .

Finally, I calibrate the model using US average data over the period 1965 - $1995 .^{28}$ Table 6 shows the results. Both the impact and the steady state effect of a $1 \%$ increase in public employment, wages of public sector employees, unemployment benefits and labor taxes are smaller in the US than in Europe, while the opposite occurs when tax rates on capital income increase. These results are due to the fact that all fiscal variables, except tax rates on capital income and the ratio of government consumption to GDP, are lower in the US than in Europe.

Differences in economic policies are often blamed for differences in the macroeconomic performance of the European countries versus the US. The model can provide an answer to the following question: what would have been the change in economic situation in Europe if fiscal policy variables were, on average, set equal to those in the US? Figure 4 plots the response of the economy to this change in fiscal policy. ${ }^{29}$ I calibrate the initial steady state equilibrium using average data of the Eu-

\footnotetext{
${ }^{28}$ Data are shown at the bottom of Table 6.

${ }^{29}$ While steady state effects are quite instructive, impact effects have to be taken with caution, because the dynamics of the model is worked out loglinearizing the system around steady state values and changes in fiscal policy variables are sizeable in this experiment.
} 
ropean countries in the sample and the final one with the averages of the US data. At the time of the policy change, employment in the private sector and output increase by $18 \%$ and $12 \%$, respectively. In the long - run, they are $18 \%$ and $9 \%$ higher than in the pre - policy change equilibrium. The capital stock decreases by $7 \%$ in the steady state. All agents in the economy, except the unemployed workers, benefit from the policy shift and income inequality substantially decreases ${ }^{30}$ Finally, public finances improves leading to a decline in the debt-to-GDP ratio.

How do these results compare with actual data? Using series from the OECD Economic Outlook from 1965 to 1995 for real output, real capital stock in the business sector, employment in the private sector, population, and purchasing power parity (PPP), I calculate real output, real capital stock in the business sector and employment in the private sector (in PPP value) as a share of population and I average them both across the ten European countries in Table 1 and in the US. I, then, compute the percentage change in per capita output, capital stock and employment in the private sector between the average values in Europe and in the US. Interestingly, results discussed above match the data pretty well (see Table 7). In fact, on average, over the period 1965 - 1995, real per capita income, and employment in the private sector as a share of population were $48 \%$ and $22 \%$ higher in the US than in Europe, while the capital stock was $23 \%$ lower in the former country than in the latter. In the model, these numbers are $9 \%, 18 \%$, and $-7 \%$. Hence, ceteris paribus, the model can explain $19 \%$ of the difference between

\footnotetext{
${ }^{30}$ Note that the experiment implies a decrease in public employment, wages of public sector employees, unemployment benefits and labor taxes and an increase in tax rates on capital income and government consumption. As discussed in section 3.3, income inequality goes up in steady state when spending on welfare and government employment increase because of the negative effects these changes have on employment, while it goes down when tax rates raise. Hence, in this experiment, the effect on inequality of lower spending and higher capital tax rates more than compensate the one due to a decrease in labor taxation.
} 
Europe and the US in real per capita income, $31 \%$ of the difference in the capital stock, and about $100 \%$ of the difference in private sector employment. Considering that we are explaining long - run values only in terms of differences in fiscal policy and that we are disregarding many variables that are important determinants of long - run growth and standard of livings, results look quite encouraging. Also, it is interesting to note how fiscal policy changes have a greater power in explaining differences in employment rates. As a matter of fact, there is quite a large literature that explains differences in structural unemployment between the US and Europe in terms of differences in generosity of the welfare state, labor taxation and flexibility of the labor market.

\section{Conclusions}

This paper studies the effects of fiscal policy on economic activity, welfare, income distribution, and public finances in a dynamic general equilibrium model with a unionized labor market. The paper shows that, in response to a debt-financed increase in public employment, wages of public sector employees, unemployment benefits, and labor taxes unions demand higher wages. As a result, employment in the private sector and the capital stock fall and the economy contracts. The paper also suggests that policies that redistribute income in favor of one type of workers can damage workers as a group. In fact, the benefit that the targeted group receives from higher disposable income can be more than compensated by the cost due to the effect that fiscal policy has on the employment rate. Simulations show that debt-financed increases of public employment, public wages and unemployment benefits increase workers' utility relative to the pre-policy change equilibrium during the transition, but not in the long-run. Instead, workers' utility decreases at any time horizon when labor taxes increase. Capitalists always benefit from increases of taxes on labor and capital income but their welfare decreases when 
public spending goes up. Our basic results concerning the other fiscal policy variables hold also when the wage of the public sector is endogenized. The negative effect of expansions in public employment are mitigated or even reversed if public spending enters the production function. Finally, we analyze the sensitivity of the results to the assumption that the government balances its intertemporal budget constraint by lump-sum transfers paid only to capitalists. Our conclusions concerning changes in public employment, wage of public employees and unemployment benefits are reinforced if the government pays lump-sum transfers to workers too. Instead, in response to an increase in tax rates on labor income, results are the opposite of those in the benchmark model. 


\section{References}

[1] Alesina A., S. Ardagna, (1998), Tales of Fiscal Adjustments, Economic Policy, October, 27, pp. 489-545.

[2] Alesina, A.; Ardagna, S.; Perotti, R. and Schiantarelli, F. (2002). Fiscal Policy, Profits and Investment, American Economic Review, June 2002, vol. 92, No. 3, pp. 571 - 589.

[3] Alesina, A.; Danninger, S. and Rostagno, M. (1999) Redistribution through Public Employment: the Case of Italy. NBER working paper $\mathrm{n} .7387$.

[4] Alesina, A. and Perotti, R. (1997a). Fiscal Adjustments in OECD Countries: Composition and Macroeconomic Effects. IMF Staff Papers (June): 210-248.

[5] Alesina, A. and Perotti, R. (1997b). The Welfare State and Competitiveness. American Economic Review 87: 921-939.

[6] Algan Y., P. Cahuc, A. Zylberberg, (2002), Public Employment. Does It Increase Unemployment? Economic Policy, April 2002, pp. 9-65.

[7] Ardagna, S., (2004), Fiscal Stabilizations: When Do They Work and Why, European Economic Review, vol. 48, No. 5, October 2004, pp. 1047-1074.

[8] Ardagna, S. (2001). Fiscal Policy Composition, Public Debt and Economic Activity. Public Choice, Volume 109, Nos. 3-4, December 2001, pp. 301-325, 2001.

[9] Barro, R. (1990). Government Spending in a Simple Model of Endogenous Growth. Journal of Political Economy 98 (October): part II S103-S125. 
[10] Baxter, M. and King, R. (1993). Fiscal Policy in General Equilibrium.American Economic Review 83 (June): 315-334.

[11] Blanchard, O. and Kahn, C. (1980). The Solution of Linear Difference Models Under Rational Expectations. Econometrica 48(5): 1305-1311.

[12] Burnside, C.; Eichenbaum, M. and Fisher, J. (2003), Fiscal Shocks and Their Consequences, NBER Working Paper no. 9772.

[13] Calmfors L., and J. Driffill, 1988, Bargaining Structure, Corporatism and Macroeconomic Performance, Economic Policy, April 1988, vol. 6, 13-62.

[14] Calmfors, L. and Horn, H. (1986). Employment policies and centralized wage-setting.Economica 53:.281-302.

[15] Cavallo, M., (2003), Government Employment and the Dynamic Effects of Fiscal Policy Shocks, mimeo NYU.

[16] Daveri, F. and Maffezzoli, M. (1999). A Numerical Approach to Fiscal Policy, Unemployment, and Growth in Europe. Bocconi University working paper.

[17] Daveri, F. and Tabellini, G. (2000). Unemployment, Growth and Taxation in Industrial Countries. Economic Policy 27 (April): 47-88.

[18] Devereux, Michael P.; Head, Allen C. and Lapham, Beverly J (1996), Monopolistic Competition, Increasing Returns and the Effects of Government Spending. Journal of Money Credit and Banking, May 1996, 28(2), pp. 233-254. 
[19] Dotsey, M. (1994). Some Unpleasant Supply Side Arithmetic. Journal of Monetary Economics v33, n3: pp. 507-524.

[20] Finn, M. (1998). Cyclical Effects of Government's Employment and Goods Purchases. International Economic Review 39(3): 635-657.

[21] Forni L. and R. Giordano, (2003), Employment in the Public Sector, CESIFO Working Paper no. 1085 .

[22] Gali J., J. D. Lopez-Salido, J. Valles, (2003), Understanding the Effects of Government Spending on Consumption, European Central Bank Working Paper no. 339.

[23] Giavazzi F., T. Jappelli, M. Pagano, (2000), Searching for Non-Linear Effects of Fiscal Policy: Evidence from Industrial and Developing Countries, European Economic Review, vol. 44, n.7, pp. $1259-1289$.

[24] Hansen G., (1985), Indivisible Labor and the Business Cycle, Journal of Monetary Economics, vol. 16, pp. 309-328.

[25] Holmund, B. (1997). Macroeconomic Implications of Cash Limits in the Public Sector. Economica 64, pp. 49-62.

[26] Horner J., L. R. Ngai, C. Olivetti, (2004), Public Enterprises and Labor Market Performance, CEP DP 610/2004.

[27] Jantti, M. (1996). Inequality in Five Countries in the 1980s: The Role of Demographic Shifts, Markets and Government Policies. Economica. vol.64, pp. 415-440. 
[28] Ludvigson, S. (1996). The Macroeconomic Effects of Government Debt in a Stochastic Growth Model. Journal of Monetary Economics 38: 25-45.

[29] Maffezzoli M., (2001), Non-Walrasian Labor Markets and Real Business Cycles, Review of Economic Dynamics, 4, pp.860-892.

[30] Malley, J. and Moutos, T. (1996). Does Government Employment "Crowd-Out” Private Employment? Evidence from Sweden. Scandinavian Journal of Economics: 98(2), pp. 289-302.

[31] McDermott, J. and Wescott, R. (1996). An Empirical Analysis of Fiscal Adjustments. IMF Staff Papers 43(4): 725-753.

[32] Mendoza, E. and Tesar, L. (1998). The International Ramifications of Tax Reforms: Supply-Side Economics in a Global Economy. American Economic Review 88(1): 226-245.

[33] Mendoza, E.; Tesar, L. and Razin, A. (1994). Effective Tax Rates in Macroeconomics: Cross Country Estimates of Tax Rates on Factor Incomes and Consumption. Journal of Monetary Economics 34(3): 297-323.

[34] Ohanian, L. (1997). The Macroeconomic Effects of War Finance in the United States: World War II and the Korean War. American Economic Review 87(1): 23-40.

[35] OECD. Economic Outlook n.62.

[36] OECD (1991). Income Distribution in OECD Countries. Social Policy Studies no. 18.

[37] Pappa, E., (2004), New-Keynesian or RBC Transmission? The Effects of Fiscal Shocks in Labor Markets, IGIER. 
[38] Ramey, V. and Shapiro, M. (1998). Costly Capital Reallocation and the Effect of Government Spending. Carnegie Rochester Conference Series on Public Policy, 48, June, pp. 145-94.

[39] Rogerson R., and R. Wright, (1988), Involuntary Unemployment in Economies with Efficient Risk Sharing, Journal of Monetary Economics, vol. 22, pp. 501-515.

[40] Rotemberg, J. and Woodford, M. (1992). Oligopolistic Pricing and the Effects of Aggregate Demand on Economic Activity. Journal of Political Economy, vol 100, no. 6, pp. 1153 -1207.

[41] Zanetti F., (2004), A Non-Walrasian Labor Market and the European Business Cycle, Boston College Working Paper no. 574. 


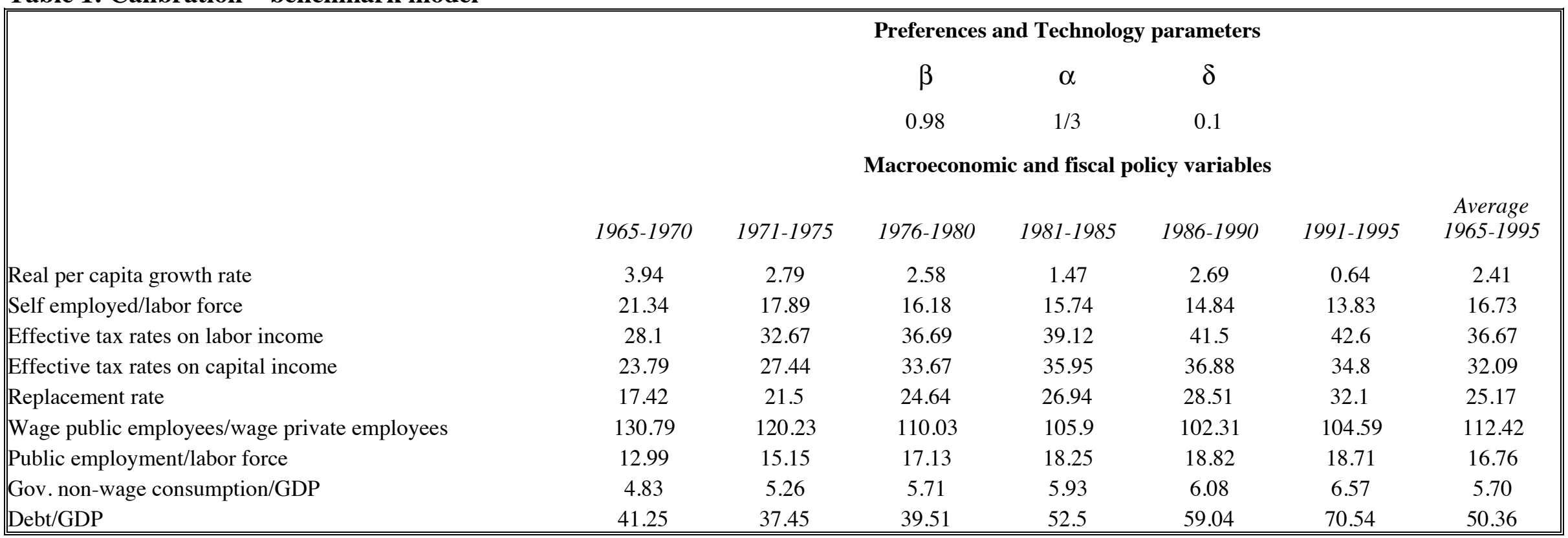

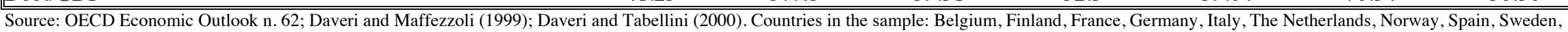

UK.

Table 2: Macroeconomic variables - benchmark model

\begin{tabular}{|c|c|c|c|c|c|c|c|}
\hline & $1965-1970$ & $1971-1975$ & $1976-1980$ & $1981-1985$ & $1986-1990$ & 1991-1995 & $\begin{array}{c}\text { Average } \\
1965-1995\end{array}$ \\
\hline & \multicolumn{7}{|c|}{ Average data } \\
\hline Capital stock/GDP & 185.47 & 190.9 & 201.2 & 211.1 & 209.7 & 218.98 & 202.61 \\
\hline Investment/GDP & 20.29 & 20.56 & 18.92 & 17.05 & 18.38 & 16.60 & 18.66 \\
\hline Total consumption/GDP & 57.91 & 58.11 & 58.84 & 57.89 & 58.16 & 58.29 & 58.19 \\
\hline Dependent employment rate ${ }^{1}$ & 77.01 & 79.84 & 78.99 & 75.80 & 76.97 & 75.44 & 77.33 \\
\hline \multirow[t]{2}{*}{ Unemployment rate } & 2.07 & 2.64 & 4.67 & 8.38 & 8.13 & 10.43 & 5.92 \\
\hline & \multicolumn{7}{|c|}{ Steady state variables generated by the model } \\
\hline Capital stock/GDP & 158.16 & 162.46 & 150.68 & 157.67 & 142.30 & 171.12 & 156.1 \\
\hline Investment/GDP & 22.05 & 20.78 & 18.95 & 18.08 & 18.06 & 18.22 & 19.37 \\
\hline Total consumption/GDP & 73.12 & 73.96 & 75.33 & 75.98 & 75.86 & 75.21 & 74.93 \\
\hline Dependent employment rate ${ }^{1}$ & 71.51 & 72.41 & 71.79 & 69.47 & 67.77 & 57.44 & 70.43 \\
\hline Unemployment rate & 7.15 & 9.70 & 12.03 & 14.79 & 17.39 & 28.73 & 12.87 \\
\hline
\end{tabular}

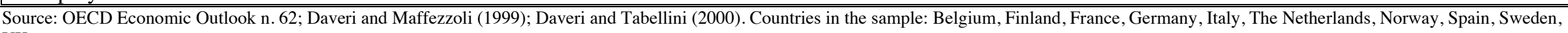
UK.

\footnotetext{
${ }^{1}$ Dependent employment rate is the sum of employment in the private and public sectors as a share of the labor force.
} 
Table 3: Effects of $1 \%$ increase in fiscal policy items - benchmark model.

\begin{tabular}{|c|c|c|c|c|c|c|c|c|c|c|c|c|}
\hline & $\begin{array}{l}\text { Impact } \\
\text { effect }\end{array}$ & $\begin{array}{l}\text { Long-run } \\
\text { effect }\end{array}$ & $\begin{array}{l}\text { Impact } \\
\text { effect }\end{array}$ & $\begin{array}{l}\text { Long-run } \\
\text { effect }\end{array}$ & $\begin{array}{l}\text { Impact } \\
\text { effect }\end{array}$ & $\begin{array}{l}\text { Long-run } \\
\text { effect }\end{array}$ & $\begin{array}{l}\text { Impact } \\
\text { effect }\end{array}$ & $\begin{array}{c}\text { Long-run } \\
\text { effect }\end{array}$ & $\begin{array}{l}\text { Impact } \\
\text { effect }\end{array}$ & $\begin{array}{l}\text { Long-run } \\
\text { effect }\end{array}$ & $\begin{array}{l}\text { Impact } \\
\text { effect }\end{array}$ & $\begin{array}{l}\text { Long-run } \\
\text { effect }\end{array}$ \\
\hline & (1) & (2) & (3) & (4) & (5) & (6) & (7) & (8) & (9) & (10) & (11) & (12) \\
\hline & \multicolumn{2}{|c|}{$\Delta \mathrm{g}$} & \multicolumn{2}{|c|}{$\Delta \mathrm{N}_{\mathrm{g}}$} & \multicolumn{2}{|c|}{$\Delta \mathrm{w}_{\mathrm{g}}$} & \multicolumn{2}{|c|}{$\Delta \mathrm{u}$} & \multicolumn{2}{|c|}{$\Delta \tau_{\mathrm{N}}$} & \multicolumn{2}{|c|}{$\Delta \tau_{\mathrm{k}}$} \\
\hline $\begin{array}{r}\text { Macroeconomy } \\
\text { Output }\end{array}$ & & & & & & & & & & & & \\
\hline Output & 0 & 0 & -0.37 & -0.55 & -0.35 & -0.53 & -0.28 & -0.41 & -0.16 & -0.24 & 0 & -0.24 \\
\hline Capital stock & 0 & 0 & 0 & -0.55 & 0 & -0.53 & 0 & -0.41 & 0 & -0.24 & 0 & -0.71 \\
\hline Investment & 0 & 0 & -0.52 & -0.55 & -0.50 & -0.53 & -0.39 & -0.41 & -0.23 & -0.24 & -0.67 & -0.71 \\
\hline Private sector employment & 0 & 0 & -0.55 & -0.55 & -0.53 & -0.53 & -0.41 & -0.41 & -0.24 & -0.24 & 0 & 0 \\
\hline Unemployment & 0 & 0 & 1.00 & 1.00 & 2.21 & 2.21 & 1.72 & 1.72 & 1.00 & 1.00 & 0 & 0 \\
\hline Rate of return on capital & 0 & 0 & -0.37 & 0 & -0.35 & 0 & -0.28 & 0 & -0.16 & 0 & 0 & 0.48 \\
\hline Private sector workers' wage rate & 0 & 0 & 0.19 & 0 & 0.18 & 0 & 0.14 & 0 & 0.08 & 0 & 0 & -0.24 \\
\hline Total consumption & -0.076 & -0.076 & -0.33 & -0.55 & -0.32 & -0.53 & -0.25 & -0.41 & -0.14 & -0.24 & 0.17 & -0.11 \\
\hline \multicolumn{13}{|l|}{ Public finances } \\
\hline$D e b t / G D P$ & 0 & 1.70 & 0.19 & 10.3 & 0.18 & 11.6 & 0.14 & 6.77 & 0.08 & -6.67 & 0 & -3.0 \\
\hline Primary deficit/GDP & 0.06 & 0.06 & 0.3 & 0.3 & 0.34 & 0.34 & 0.19 & 0.19 & -0.25 & -0.25 & -0.11 & -0.11 \\
\hline Primary spending/GDP & 0.06 & 0.06 & 0.43 & 0.43 & 0.47 & 0.47 & 0.22 & 0.22 & 0.11 & 0.11 & 0 & 0 \\
\hline Revenue/GDP & 0 & 0 & 0.13 & 0.13 & 0.13 & 0.13 & 0.04 & 0.04 & 0.35 & 0.35 & 0.11 & 0.11 \\
\hline Primary spending & 0.17 & 0.17 & 0.92 & 0.73 & 1.06 & 0.88 & 0.40 & 0.26 & 0.16 & 0.08 & 0 & -0.24 \\
\hline Revenue & 0 & 0 & -0.06 & -0.25 & -0.05 & -0.23 & -0.19 & -0.33 & 0.64 & 0.56 & 0.24 & 0.007 \\
\hline \multicolumn{13}{|l|}{ Welfare costs } \\
\hline "hypothetical" household & \multicolumn{2}{|c|}{0.07} & \multicolumn{2}{|c|}{0.51} & \multicolumn{2}{|c|}{0.56} & \multicolumn{2}{|c|}{0.34} & \multicolumn{2}{|c|}{0.25} & \multicolumn{2}{|c|}{0.08} \\
\hline capitalist & \multicolumn{2}{|c|}{0.40} & \multicolumn{2}{|c|}{2.63} & \multicolumn{2}{|c|}{2.94} & \multicolumn{2}{|c|}{1.72} & \multicolumn{2}{|c|}{-1.50} & \multicolumn{2}{|c|}{-0.49} \\
\hline "hypothetical" worker & \multicolumn{2}{|c|}{0} & \multicolumn{2}{|c|}{0.09} & \multicolumn{2}{|c|}{0.08} & \multicolumn{2}{|c|}{0.06} & \multicolumn{2}{|c|}{0.61} & \multicolumn{2}{|c|}{0.20} \\
\hline private sector employee & \multicolumn{2}{|c|}{0} & \multicolumn{2}{|c|}{-0.03} & \multicolumn{2}{|c|}{-0.03} & & .02 & & 56 & & 20 \\
\hline public sector employee & & 0 & & .03 & & 00 & & .02 & & 56 & & 20 \\
\hline unemployed & & 0 & & .03 & & 03 & & .99 & & .01 & & 20 \\
\hline Income distribution & & & & & & & & & & & & \\
\hline Gini coeffcient & 0 & 0.49 & -0.14 & 2.79 & 0.26 & 3.53 & -0.06 & 1.88 & 0.42 & -1.50 & -0.28 & -1.04 \\
\hline
\end{tabular}

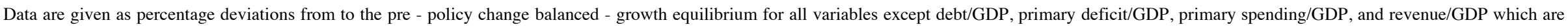

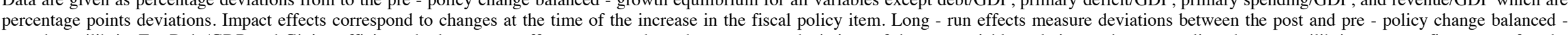

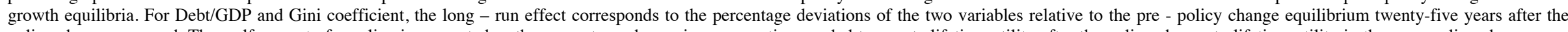

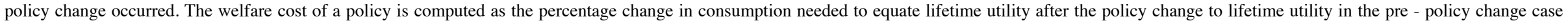
Primary deficit: a positive change in the primary deficit means that the primary balance deteriorates with respect to its value in the pre - policy change balanced - growth equilibrium. 
Table 4: Effects of $1 \%$ increase in fiscal policy items - Model with endogenous public employment and public wages.

\begin{tabular}{|c|c|c|c|c|c|c|c|c|c|c|}
\hline & $\begin{array}{l}\text { Impact } \\
\text { effect }\end{array}$ & $\begin{array}{c}\text { Long-run } \\
\text { effect }\end{array}$ & $\begin{array}{l}\text { Impact } \\
\text { effect }\end{array}$ & $\begin{array}{l}\text { Long-run } \\
\text { effect }\end{array}$ & $\begin{array}{l}\text { Impact } \\
\text { effect }\end{array}$ & $\begin{array}{l}\text { Long-run } \\
\text { effect }\end{array}$ & $\begin{array}{l}\text { Impact } \\
\text { effect }\end{array}$ & $\begin{array}{l}\text { Long-run } \\
\text { effect }\end{array}$ & $\begin{array}{l}\text { Impact } \\
\text { effect }\end{array}$ & $\begin{array}{l}\text { Long-run } \\
\text { effect }\end{array}$ \\
\hline & (1) & (2) & (3) & (4) & (7) & (8) & (9) & (10) & (11) & (12) \\
\hline & \multicolumn{2}{|c|}{$\Delta \mathrm{g}$} & \multicolumn{2}{|c|}{$\Delta \Omega$} & \multicolumn{2}{|c|}{$\Delta \mathrm{u}$} & \multicolumn{2}{|c|}{$\Delta \tau_{\mathrm{N}}$} & \multicolumn{2}{|c|}{$\Delta \tau_{\mathrm{k}}$} \\
\hline Macroeconomy & & & & & & & & & & \\
\hline Output & 0 & 0 & -0.08 & -0.17 & -0.38 & -0.87 & -0.22 & -0.51 & 0 & -0.60 \\
\hline Capital stock & 0 & 0 & 0 & -0.17 & 0 & -0.87 & 0 & -0.50 & 0 & -1.07 \\
\hline Investment & 0 & 0 & -0.016 & -0.18 & -0.07 & -0.93 & -0.05 & -0.52 & -0.10 & -1.12 \\
\hline Private sector employment & 0 & 0 & -0.11 & -0.17 & -0.57 & -0.87 & -0.33 & -0.51 & 0 & -0.37 \\
\hline Public sector employment & 0 & 0 & 0.18 & 0.24 & -0.18 & 0.48 & -0.12 & 0.30 & 0 & 0.54 \\
\hline Unemployment & 0 & 0 & 0.11 & 0.17 & 1.44 & 1.74 & 0.84 & 1.01 & 0 & 0.37 \\
\hline Rate of return on capital & 0 & 0 & -0.08 & -0.0004 & -0.38 & -0.003 & -0.22 & -0.001 & 0 & 0.47 \\
\hline Private sector workers' wage rate & 0 & 0 & 0.038 & 0.0002 & 0.19 & 0.01 & 0.11 & 0.0005 & 0 & -0.23 \\
\hline Public sector workers' wage rate & 0 & 0 & -0.008 & -0.07 & 0.11 & -0.20 & 0.06 & -0.12 & 0 & -0.384 \\
\hline Total consumption & -0.08 & -0.08 & -0.09 & -0.17 & -0.46 & -0.86 & -0.27 & -0.50 & 0.02 & -0.47 \\
\hline \multicolumn{11}{|l|}{ Public finances } \\
\hline Debt/GDP & 0 & 1.79 & 0.04 & 2.27 & 0.19 & 9.37 & 0.11 & -7.58 & 0 & -3.41 \\
\hline Primary deficit/GDP & 0.06 & 0.06 & 0.07 & 0.11 & 0.30 & 0.49 & -0.24 & -0.13 & -0.11 & 0.12 \\
\hline Primary spending/GDP & 0.06 & 0.06 & 0.10 & 0.16 & 0.34 & 0.61 & 0.15 & 0.31 & 0 & 0.33 \\
\hline Revenue/GDP & 0 & 0 & 0.03 & 0.05 & 0.04 & 0.13 & 0.40 & 0.44 & 0.11 & 0.21 \\
\hline Primary spending & 0.12 & 0.12 & 0.14 & 0.15 & 0.32 & 0.39 & 0.10 & 0.14 & 0 & 0.09 \\
\hline Revenue & 0 & 0 & -0.01 & -0.07 & -0.29 & -0.61 & 0.60 & 0.42 & 0.22 & -0.17 \\
\hline \multicolumn{11}{|l|}{ Welfare costs } \\
\hline "hypothetical" household & \multicolumn{2}{|c|}{0.31} & \multicolumn{2}{|c|}{0.52} & \multicolumn{2}{|c|}{2.40} & \multicolumn{2}{|c|}{-0.41} & \multicolumn{2}{|c|}{0.32} \\
\hline capitalist & \multicolumn{2}{|c|}{0.18} & \multirow{2}{*}{\multicolumn{2}{|c|}{3.14}} & \multicolumn{2}{|c|}{15.27} & \multicolumn{2}{|c|}{-5.20} & \multicolumn{2}{|c|}{1.41} \\
\hline "hypothetical" worker & \multicolumn{2}{|c|}{0} & 0.0001 & & \multicolumn{2}{|c|}{-0.005} & \multicolumn{2}{|c|}{0.57} & \multicolumn{2}{|c|}{0.10} \\
\hline private sector employee & \multicolumn{2}{|c|}{0} & \multicolumn{2}{|c|}{-0.02} & \multicolumn{2}{|c|}{-0.13} & \multicolumn{2}{|c|}{0.50} & \multicolumn{2}{|c|}{0.08} \\
\hline public sector employee & \multicolumn{2}{|c|}{0} & \multicolumn{2}{|c|}{0.02} & & & & & & \\
\hline unemployed & & & & & & & & 07 & & \\
\hline Income distribution & & & & & & & & & & \\
\hline Gini coeffcient & 0 & 0.62 & -0.05 & 0.72 & -0.22 & 2.89 & 0.29 & -2.42 & -0.36 & -1.58 \\
\hline
\end{tabular}

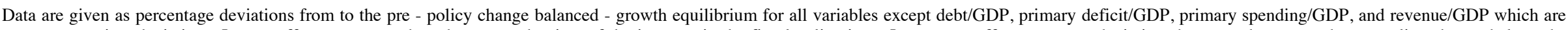

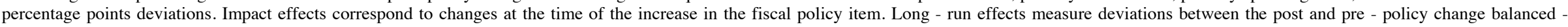

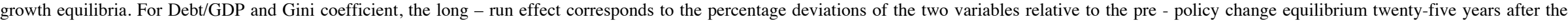

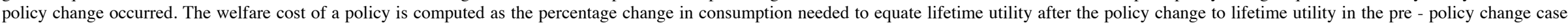
Primary deficit: a positive change in the primary deficit means that the primary balance deteriorates with respect to its value in the pre - policy change balanced - growth equilibrium. 
Table 5: Effects of $1 \%$ increase in fiscal policy items - Lump-sum transfers equally distributed to different households.

\begin{tabular}{|c|c|c|c|c|c|c|c|c|c|c|c|c|}
\hline & $\begin{array}{l}\text { Impact } \\
\text { effect }\end{array}$ & $\begin{array}{l}\text { Long-run } \\
\text { effect }\end{array}$ & $\begin{array}{l}\text { Impact } \\
\text { effect }\end{array}$ & $\begin{array}{l}\text { Long-run } \\
\text { effect }\end{array}$ & $\begin{array}{l}\text { Impact } \\
\text { effect }\end{array}$ & $\begin{array}{c}\text { Long-run } \\
\text { effect }\end{array}$ & $\begin{array}{c}\text { Impact } \\
\text { effect }\end{array}$ & $\begin{array}{l}\text { Long-run } \\
\text { effect }\end{array}$ & $\begin{array}{c}\text { Impact } \\
\text { effect }\end{array}$ & $\begin{array}{l}\text { Long-run } \\
\text { effect }\end{array}$ & $\begin{array}{c}\text { Impact } \\
\text { effect }\end{array}$ & $\begin{array}{c}\text { Long-run } \\
\text { effect }\end{array}$ \\
\hline & (1) & (2) & (3) & (4) & (5) & (6) & (7) & (8) & (9) & (10) & (11) & (12) \\
\hline & \multicolumn{2}{|c|}{$\Delta \mathrm{g}$} & \multicolumn{2}{|c|}{$\Delta \mathrm{N}_{\mathrm{g}}$} & \multicolumn{2}{|c|}{$\Delta \mathrm{w}_{\mathrm{g}}$} & \multicolumn{2}{|c|}{$\Delta \mathrm{u}$} & \multicolumn{2}{|c|}{$\Delta \tau_{\mathrm{N}}$} & \multicolumn{2}{|c|}{$\Delta \tau_{\mathrm{k}}$} \\
\hline Macroeconomy & & & & & & & & & & & & \\
\hline Output & -0.02 & -0.03 & -0.29 & -0.44 & -0.14 & -0.22 & -0.07 & -0.10 & 0.10 & 0.15 & 0.03 & -0.18 \\
\hline Capital stock & 0.00 & -0.03 & 0.00 & -0.44 & 0.00 & -0.22 & 0.00 & -0.10 & 0.00 & 0.15 & 0.00 & -0.66 \\
\hline Investment & -0.02 & -0.03 & -0.36 & -0.44 & -0.18 & -0.22 & -0.08 & -0.10 & 0.12 & 0.15 & -0.54 & -0.66 \\
\hline Private sector employment & -0.03 & -0.03 & -0.44 & -0.44 & -0.22 & -0.22 & -0.10 & -0.10 & 0.15 & 0.15 & 0.05 & 0.05 \\
\hline Unemployment & 0.51 & 0.51 & 3.11 & 3.11 & 3.96 & 3.96 & 1.81 & 1.81 & -2.66 & -2.66 & -0.96 & -0.96 \\
\hline Rate of return on capital & -0.02 & 0.00 & -0.29 & 0.00 & -0.14 & 0.00 & -0.07 & 0.00 & 0.10 & 0.00 & 0.03 & 0.47 \\
\hline Private sector workers' wage rate & 0.01 & 0.00 & 0.15 & 0.00 & 0.07 & 0.00 & 0.03 & 0.00 & -0.05 & 0.00 & -0.02 & -0.24 \\
\hline Total consumption & -0.09 & -0.10 & -0.27 & -0.44 & -0.14 & -0.22 & -0.06 & -0.10 & 0.09 & 0.15 & 0.18 & -0.06 \\
\hline \multicolumn{13}{|l|}{ Public finances } \\
\hline Primary deficit/GDP & 0.07 & 0.07 & 0.22 & 0.22 & 0.19 & 0.19 & 0.04 & 0.04 & -0.36 & -0.36 & -0.12 & -0.12 \\
\hline Primary spending/GDP & 0.07 & 0.07 & 0.32 & 0.32 & 0.28 & 0.28 & 0.05 & 0.05 & -0.05 & -0.05 & -0.02 & -0.02 \\
\hline Revenue/GDP & 0.00 & 0.00 & 0.11 & 0.11 & 0.09 & 0.09 & 0.01 & 0.01 & 0.31 & 0.31 & 0.10 & 0.10 \\
\hline Primary spending & 0.24 & 0.23 & 0.91 & 0.77 & 0.91 & 0.84 & 0.11 & 0.08 & -0.11 & -0.06 & -0.04 & -0.26 \\
\hline Revenue & -0.01 & -0.02 & -0.04 & -0.19 & 0.07 & -0.01 & -0.05 & -0.08 & 0.82 & 0.87 & 0.28 & 0.06 \\
\hline \multicolumn{13}{|l|}{ Welfare costs } \\
\hline "hypothetical" household & \multicolumn{2}{|c|}{0.11} & \multicolumn{2}{|c|}{0.48} & \multicolumn{2}{|c|}{0.29} & \multicolumn{2}{|c|}{0.10} & \multicolumn{2}{|c|}{-0.26} & \multicolumn{2}{|c|}{0.01} \\
\hline capitalist & \multicolumn{2}{|c|}{0.21} & \multicolumn{2}{|c|}{0.97} & \multicolumn{2}{|c|}{0.72} & \multicolumn{2}{|c|}{0.19} & \multicolumn{2}{|c|}{-1.11} & \multicolumn{2}{|c|}{0.00} \\
\hline "hypothetical" worker & \multicolumn{2}{|c|}{0.10} & \multicolumn{2}{|c|}{0.39} & \multicolumn{2}{|c|}{0.21} & \multicolumn{2}{|c|}{0.08} & \multicolumn{2}{|c|}{-0.09} & \multicolumn{2}{|c|}{0.01} \\
\hline private sector employee & \multicolumn{2}{|c|}{0.08} & \multicolumn{2}{|c|}{0.31} & \multicolumn{2}{|c|}{0.26} & & 06 & & 01 & & 04 \\
\hline public sector employee & & .07 & & .28 & & 57 & & 05 & & 06 & & 05 \\
\hline Unemployed & & 16 & & .63 & & 51 & & .49 & & .87 & & .11 \\
\hline Income distribution & & & & & & & & & & & & \\
\hline Gini coeffcient & 0.10 & 0.10 & 0.11 & 0.11 & 0.85 & 0.85 & 0.06 & 0.06 & 0.12 & 0.12 & -0.84 & -0.84 \\
\hline
\end{tabular}

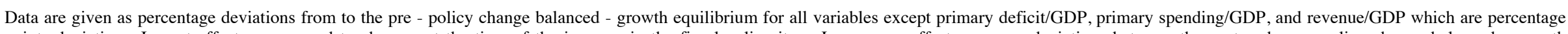

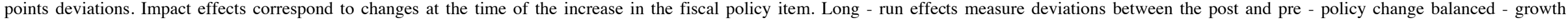

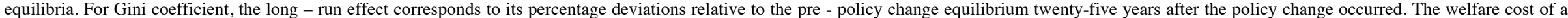

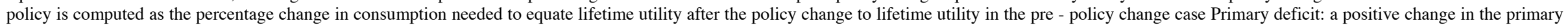
deficit means that the primary balance deteriorates with respect to its value in the pre - policy change balanced - growth equilibrium. 
Table 6: Effects of $1 \%$ increase in fiscal policy items - US average data.

\begin{tabular}{|c|c|c|c|c|c|c|c|c|c|c|c|c|}
\hline & $\begin{array}{c}\text { Impact } \\
\text { effect }\end{array}$ & $\begin{array}{l}\text { Long-run } \\
\text { effect }\end{array}$ & $\begin{array}{l}\text { Impact } \\
\text { effect }\end{array}$ & $\begin{array}{c}\text { Long-run } \\
\text { effect }\end{array}$ & $\begin{array}{c}\text { Impact } \\
\text { effect }\end{array}$ & $\begin{array}{l}\text { Long-run } \\
\text { effect }\end{array}$ & $\begin{array}{l}\text { Impact } \\
\text { effect }\end{array}$ & $\begin{array}{c}\text { Long-run } \\
\text { effect }\end{array}$ & $\begin{array}{l}\text { Impact } \\
\text { effect }\end{array}$ & $\begin{array}{l}\text { Long-run } \\
\text { effect }\end{array}$ & $\begin{array}{c}\text { Impact } \\
\text { effect }\end{array}$ & $\begin{array}{c}\text { Long-run } \\
\text { effect }\end{array}$ \\
\hline & (1) & (2) & (3) & (4) & (5) & (6) & (7) & (8) & (9) & (10) & (11) & (12) \\
\hline Macroeconomy & \multicolumn{2}{|c|}{$\Delta \mathrm{g}$} & \multicolumn{2}{|c|}{$\Delta \mathrm{N}_{\mathrm{g}}$} & \multicolumn{2}{|c|}{$\Delta \mathrm{w}_{\mathrm{g}}$} & \multicolumn{2}{|c|}{$\Delta \mathrm{u}$} & \multicolumn{2}{|c|}{$\Delta \tau_{\mathrm{N}}$} & \multicolumn{2}{|c|}{$\Delta \tau_{\mathrm{k}}$} \\
\hline Output & 0 & 0 & -0.19 & -0.28 & -0.11 & -0.17 & -0.04 & -0.06 & -0.01 & -0.02 & 0 & -0.37 \\
\hline Capital stock & 0 & 0 & 0 & -0.28 & 0 & -0.17 & 0 & -0.06 & 0 & -0.02 & 0 & -1.1 \\
\hline Investment & 0 & 0 & -0.28 & -0.28 & -0.17 & -0.17 & -0.06 & -0.06 & -0.02 & -0.02 & -1.1 & -1.1 \\
\hline Private sector employment & 0 & 0 & -0.28 & -0.28 & -0.17 & -0.17 & -0.06 & -0.06 & -0.02 & -0.02 & 0 & 0 \\
\hline Unemployment & 0 & 0 & 1 & 1 & 2.38 & 2.38 & 0.83 & 0.83 & 0.28 & 0.28 & 0 & 0 \\
\hline Rate of return on capital & 0 & 0 & -0.19 & 0 & -0.11 & 0 & -0.04 & 0 & -0.01 & 0 & 0 & 0.74 \\
\hline Private sector workers' wage rate & 0 & 0 & 0.09 & 0 & 0.06 & 0 & 0.02 & 0 & 0.007 & 0 & 0 & -0.37 \\
\hline Total consumption & -0.09 & -0.09 & -0.17 & -0.28 & -0.10 & -0.17 & -0.03 & -0.06 & -0.01 & -0.02 & 0.23 & 0.21 \\
\hline \multicolumn{13}{|l|}{ Public finances } \\
\hline Debt/GDP & 0 & 1.99 & 0.09 & 5.50 & 0.05 & 5.06 & 0.02 & 0.82 & 0.006 & -6.07 & 0 & -3.73 \\
\hline Primary deficit/GDP & 0.07 & 0.07 & 0.15 & 0.15 & 0.15 & 0.15 & 0.02 & 0.02 & -0.20 & -0.20 & -0.14 & -0.14 \\
\hline Primary spending/GDP & 0.07 & 0.07 & 0.20 & 0.20 & 0.20 & 0.20 & 0.023 & 0.023 & 0.005 & 0.005 & 0 & 0 \\
\hline Revenue/GDP & 0 & 0 & 0.05 & 0.05 & 0.05 & 0.05 & 0.002 & 0.002 & 0.21 & 0.21 & 0.14 & 0.14 \\
\hline Primary spending & 0.3 & 0.3 & 0.71 & 0.62 & 0.76 & 0.70 & 0.06 & 0.04 & 0.01 & 0.003 & 0 & -0.37 \\
\hline Revenue & 0 & 0 & -0.04 & -0.14 & 0.01 & -0.04 & -0.03 & -0.05 & 0.59 & 0.58 & 0.40 & 0.03 \\
\hline \multicolumn{13}{|l|}{ Welfare costs } \\
\hline "hypothetical" household & \multicolumn{2}{|c|}{0.04} & \multicolumn{2}{|c|}{0.16} & \multicolumn{2}{|c|}{0.13} & \multicolumn{2}{|c|}{0.03} & \multicolumn{2}{|c|}{0.20} & \multicolumn{2}{|c|}{0.23} \\
\hline capitalist & \multicolumn{2}{|c|}{0.42} & \multicolumn{2}{|c|}{1.23} & \multicolumn{2}{|c|}{1.11} & \multicolumn{2}{|c|}{0.18} & \multicolumn{2}{|c|}{-1.26} & \multicolumn{2}{|c|}{-0.51} \\
\hline "hypothetical" worker & \multicolumn{2}{|c|}{0} & \multicolumn{2}{|c|}{0.06} & \multicolumn{2}{|c|}{0.03} & \multicolumn{2}{|c|}{0.01} & \multicolumn{2}{|c|}{0.34} & \multicolumn{2}{|c|}{0.31} \\
\hline private sector employee & \multicolumn{2}{|c|}{0} & \multicolumn{2}{|c|}{-0.01} & \multicolumn{2}{|c|}{-0.008} & & 003 & & 34 & & 31 \\
\hline public sector employee & & 0 & & .01 & & 98 & & 003 & & 34 & & 31 \\
\hline unemployed & & 0 & & .01 & & 008 & & .97 & & 001 & & 31 \\
\hline Income distribution & & & & & & & & & & & & \\
\hline Gini coeffcient & 0 & 0.52 & -0.04 & 1.41 & 0.29 & 1.61 & 0.02 & 0.24 & 0.25 & -1.36 & -1.09 & -1.18 \\
\hline
\end{tabular}

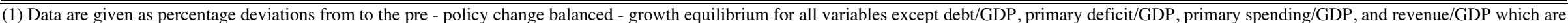

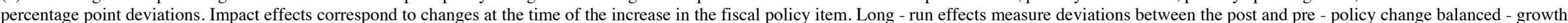

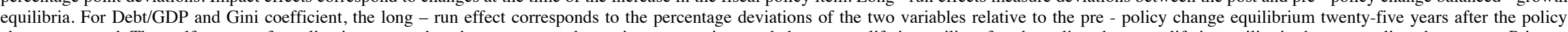

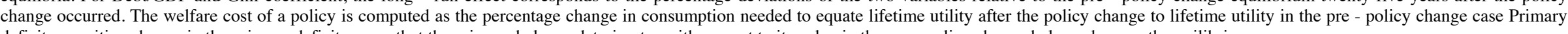
deficit: a positive change in the primary deficit means that the primary balance deteriorates with respect to its value in the pre - policy change balanced - growth equilibrium.

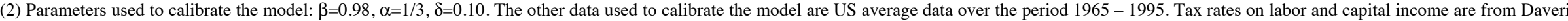

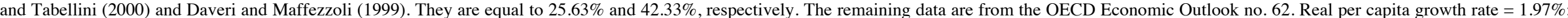

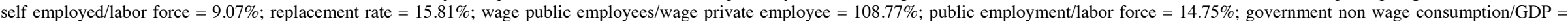
$6.65 \% ; \mathrm{debt} / \mathrm{GDP}=46.73 \%$. 
Table 7: Fiscal policy and macroeconomic performance in Europe and in the US

\begin{tabular}{|c|c|c|c|c|c|}
\hline & (1) & (2) & (3) & (4) & (5) \\
\hline & $\begin{array}{c}\text { Europe } \\
\text { average data } \\
1965-1995\end{array}$ & $\begin{array}{c}\text { US } \\
\text { average data } \\
1965-1995\end{array}$ & $\begin{array}{c}\% \Delta \text { of variables } \\
\text { from EU average } \\
\text { data to US average } \\
\text { data }\end{array}$ & $\begin{array}{l}\% \Delta \text { of variables } \\
\text { predicted by model. } \\
\\
\text { Initial steady state } \\
\text { calibrated with EU } \\
\text { average data } \\
\text { Final steady state } \\
\text { calibrated with US } \\
\text { average data }\end{array}$ & $\begin{array}{l}\text { Fraction of the } \\
\text { change in the data } \\
\text { explained by the } \\
\text { model } \\
(5) /(3)\end{array}$ \\
\hline \multicolumn{6}{|l|}{ Fiscal policy } \\
\hline Effective tax rates on labor income & 36.67 & 25.63 & -30.16 & & \\
\hline Effective tax rates on capital income & 32.09 & 42.33 & 31.91 & & \\
\hline Employment in public sector/population & 7.58 & 6.71 & -11.47 & & \\
\hline Public employment/labor force & 16.76 & 14.75 & -11.99 & & \\
\hline Wage public employees/wage private employees & 112.42 & 108.77 & -3.25 & & \\
\hline Replacement rate & 25.17 & 15.81 & -37.19 & & \\
\hline Gov. non-wage consumption/GDP & 5.70 & 6.65 & 16.66 & & \\
\hline \multicolumn{6}{|l|}{ Macroeconomy } \\
\hline Real per capita GDP (PPP values) & 13413.67 & 19862.72 & 48.07 & 9.09 & 18.91 \\
\hline Real per capita capital stock (PPP values) & 27674.86 & 21220.84 & -23.32 & -7.34 & 31.47 \\
\hline Employment in private sector/population & 26.76 & 32.57 & 21.70 & 18.37 & 84.65 \\
\hline Employment in private sector/labor force & 60.57 & 71.45 & 17.96 & 18.37 & 102.28 \\
\hline
\end{tabular}

Source: OECD Economic Outlook n. 62; Daveri and Maffezzoli (1999); Daveri and Tabellini (2000). 
Figure 1: Effects of a $1 \%$ increase in public spending and tax revenue variables - benchmark model
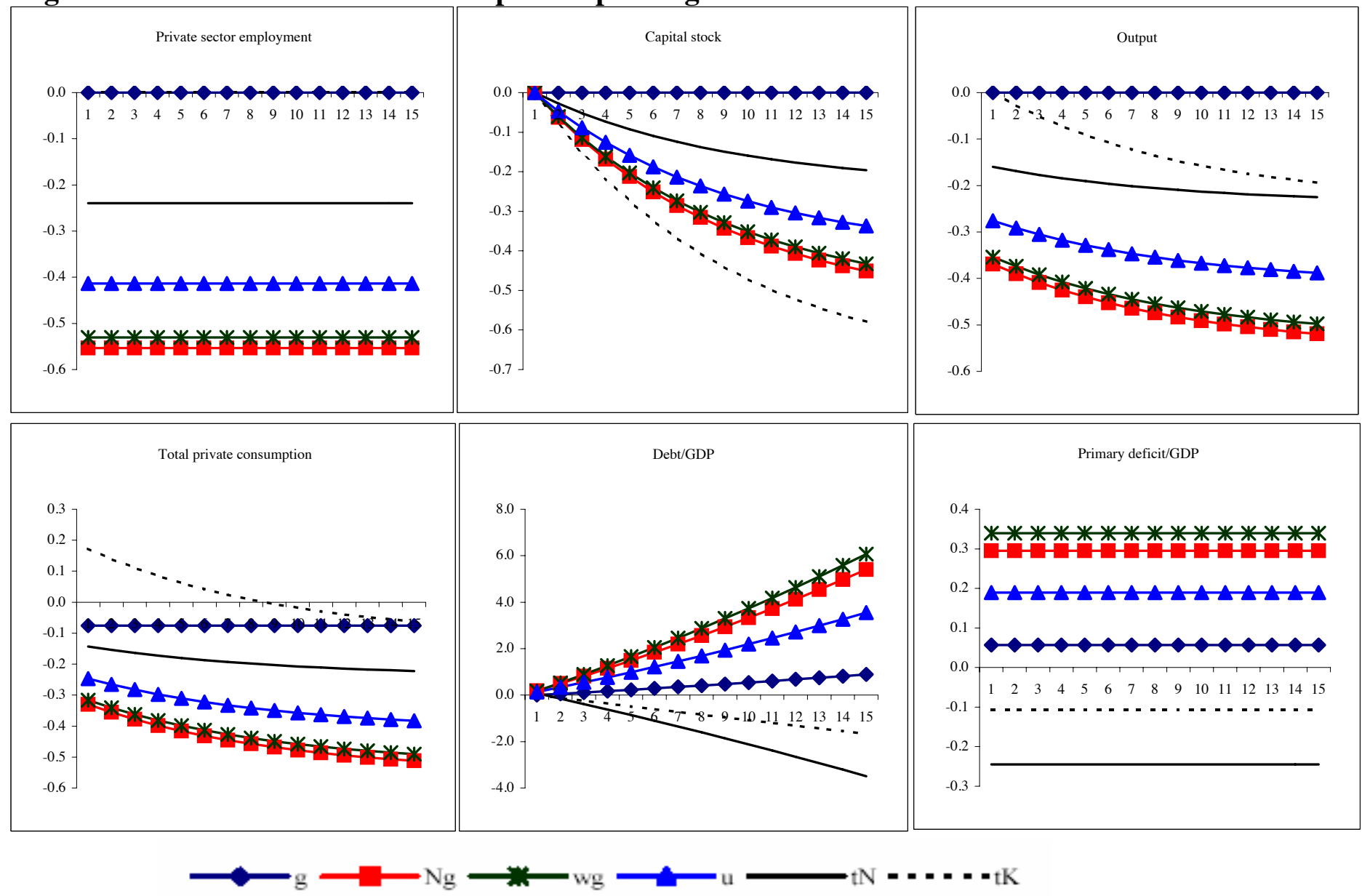

Figure 2: Effects of a $1 \%$ increase in public employment
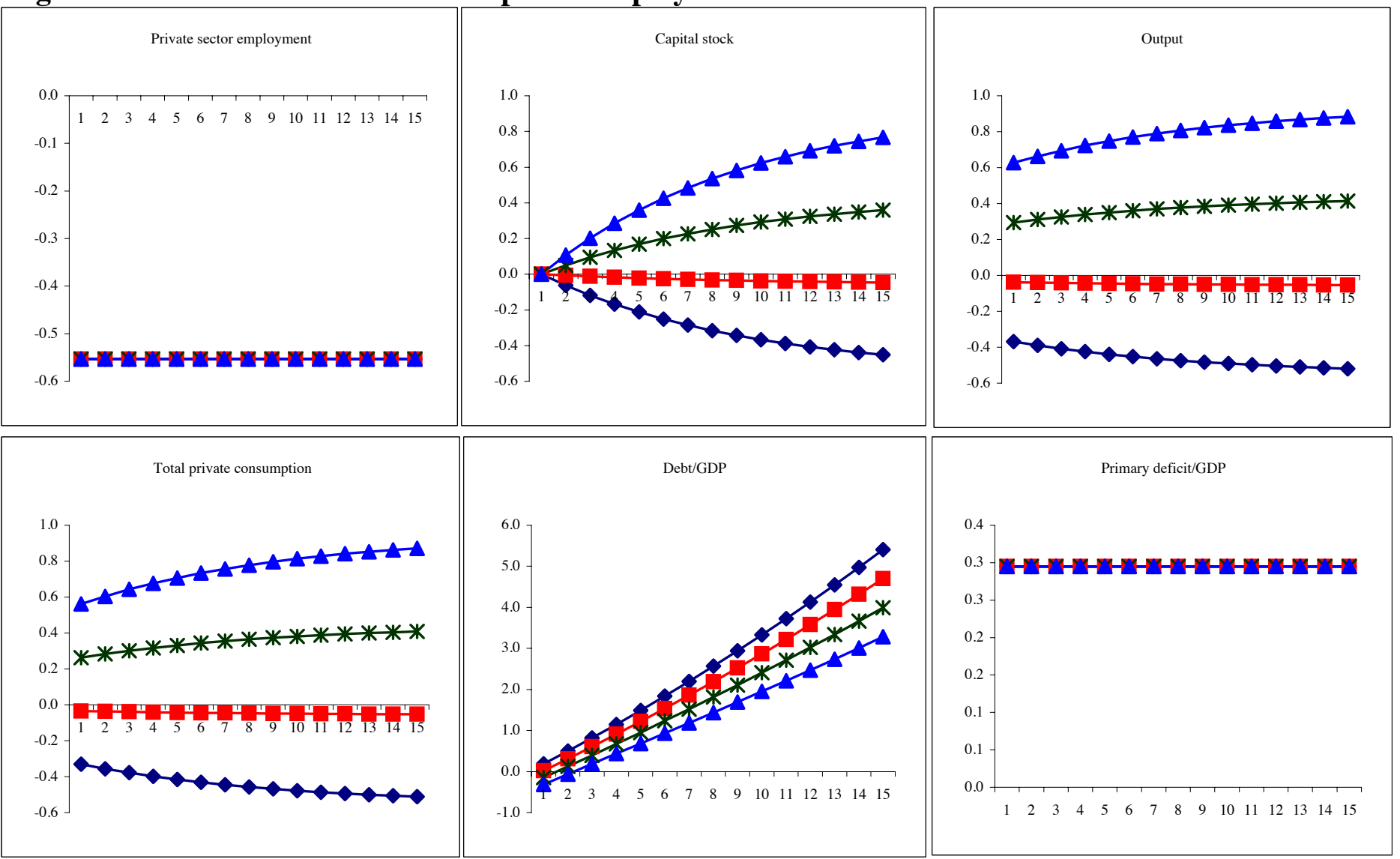

$\longrightarrow \lambda=0$

$\lambda=0.3$

$\lambda=0.6$ $\lambda=1$ 
Figure 3: Benchmark model and model with endogenous public employment and public wages

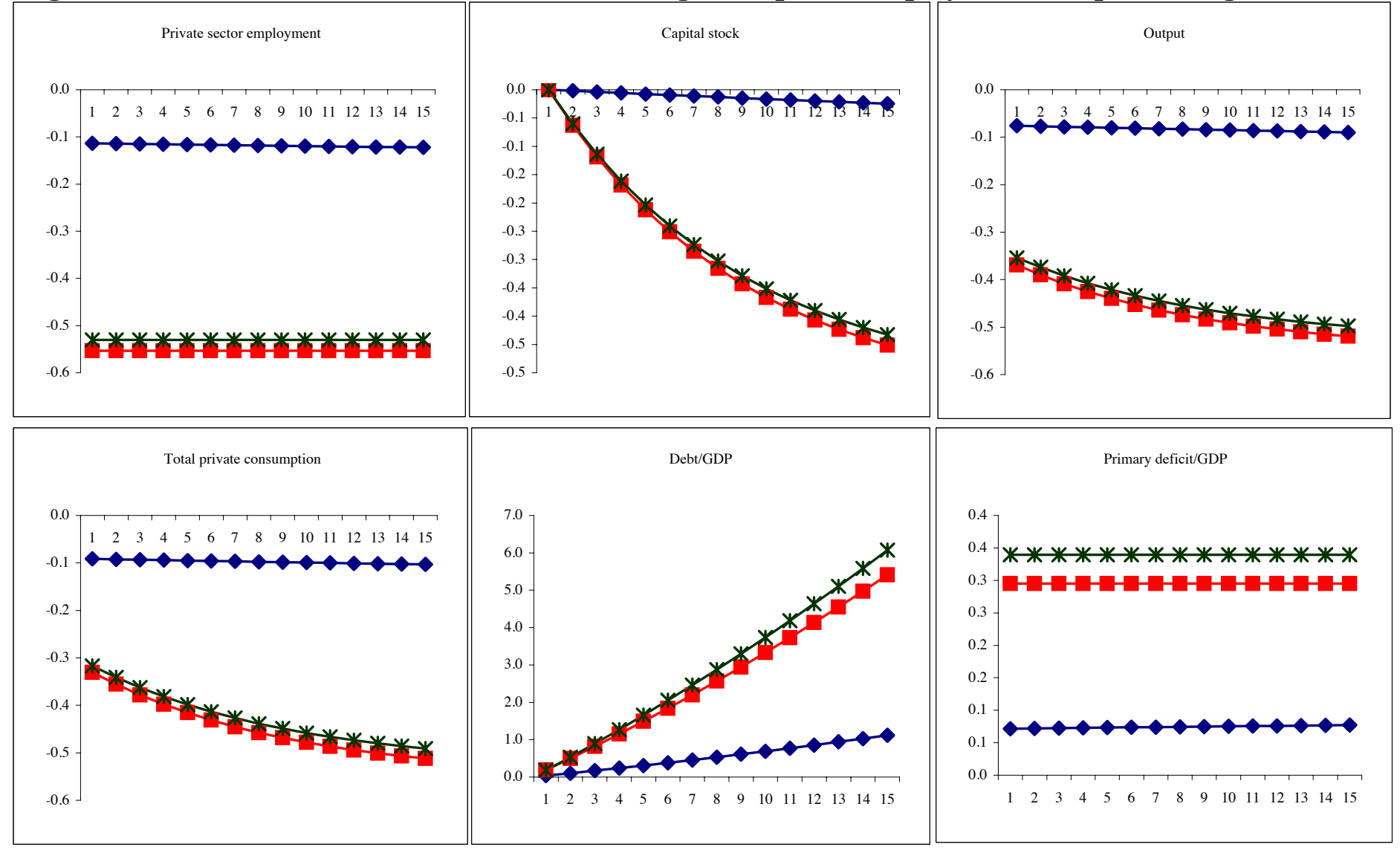

- Benchmark model - $1 \%$ shock to $\mathrm{Ng} \longrightarrow$ Benchmark model - $1 \%$ shock to $\mathrm{w}_{\mathrm{g}}$

$\longrightarrow$ Model with endogenous public employment and public wages - $1 \%$ shock to $\Omega$

Figure 4: Fiscal policy in Europe versus the United States ${ }^{(i)}$

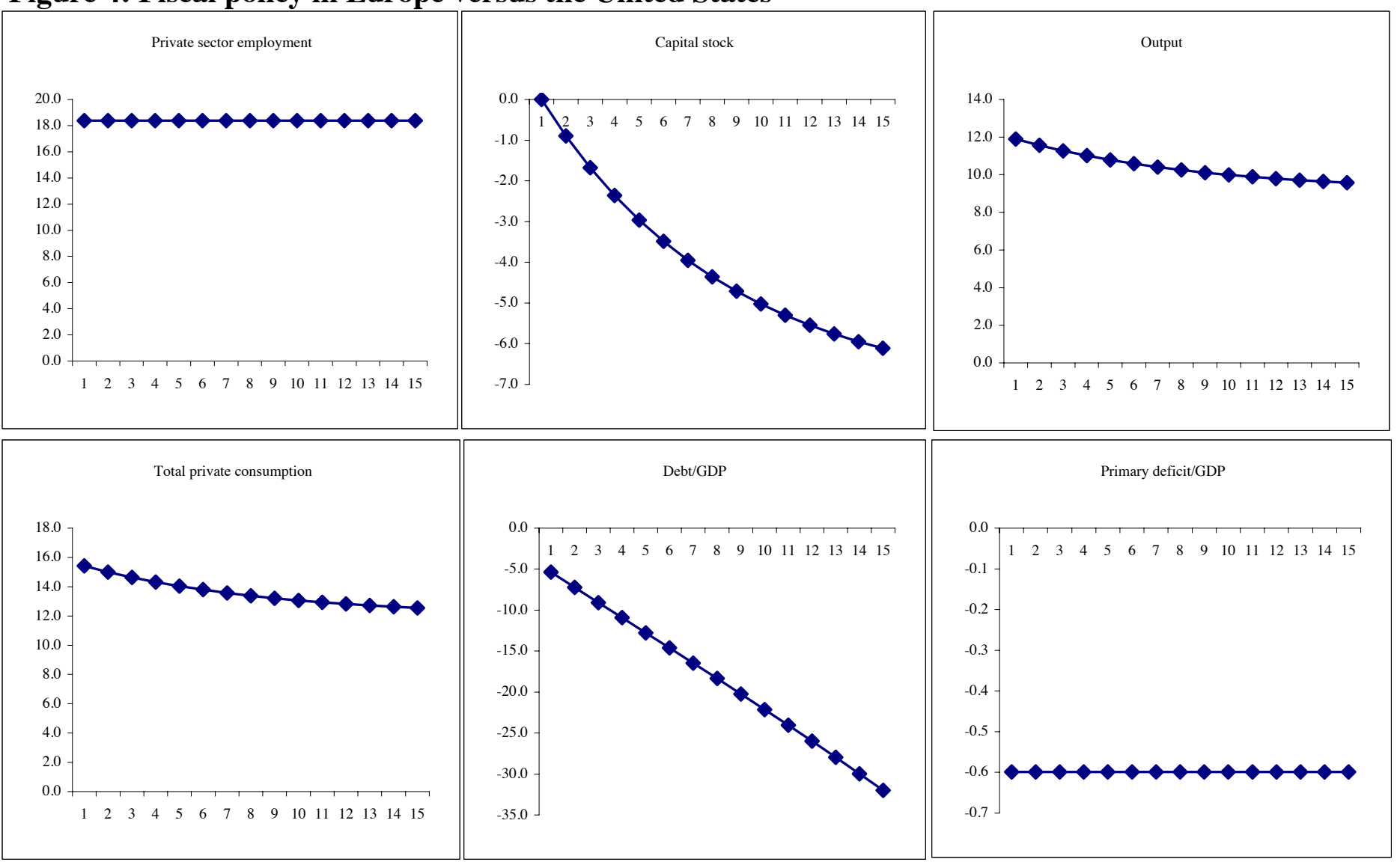

(i) Experiment: Fiscal policy variables assume the values of the average data of the European countries in the sample in the initial steady state equilibrium.

Fiscal policy variables permanently change to the averages of the US data at time 1 . 